\title{
A Single Packer Method for Characterizing Water Contributing Fractures in Crystalline Bedrock Wells
}

Neil Flahive

University of Connecticut - Storrs, neil.a.flahive@gmail.com

\section{Recommended Citation}

Flahive, Neil, "A Single Packer Method for Characterizing Water Contributing Fractures in Crystalline Bedrock Wells" (2017). Master's Theses. 1043.

https://opencommons.uconn.edu/gs_theses/1043 


\title{
A Single Packer Method for Characterizing Water Contributing Fractures in Crystalline Bedrock Wells
}

\author{
Neil A. Flahive \\ B.S., University of Connecticut, 2013
}

\begin{abstract}
A Thesis
Submitted in Partial Fulfillment of the

Requirements for the Degree of

Master of Science
\end{abstract}

At the

University of Connecticut

2017 


\section{APPROVAL PAGE}

Master of Science Thesis

\section{A Single Packer Method for Characterizing Water Contributing Fractures in}

\section{Crystalline Bedrock Wells}

Presented by

Neil A. Flahive, B.S.

Major Advisor

Gary Robbins

Associate Advisor

Glenn Warner

Associate Advisor

Meredith Metcalf

University of Connecticut

2017 


\section{Acknowledgements}

Foremost, I would like to express my gratitude to my advisor Dr. Gary Robbins, whose enthusiasm and dedication to my research made this possible. For the continuous guidance and support throughout my graduate career, thank you. Your imprinted wisdom, passion, and humor will leave with me as I move forward in life.

I would also like to thank the associate members on my advisory committee, Dr. Glenn Warner and Dr. Meredith Metcalf, for their support and interest in my research. Thank you to my fellow graduate students, Sarah Vitale and Stephanie Phillips, for your dependability and assistance throughout this research. In addition, I want to thank the USGS Office of Groundwater, Branch of Geophysics, for allowing access to the wells on site in order for this research to be conducted.

Finally, I would like to extend a special thanks to my parents, Paul and Eileen and to my brother, Richard for their unending support, love, and encouragement in all my endeavors. This thesis is dedicated to you. 


\section{TABLE OF CONTENTS}

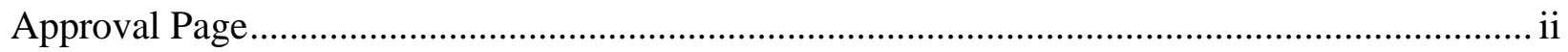

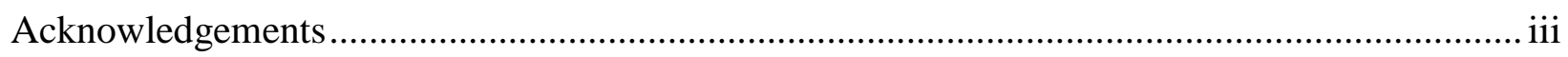

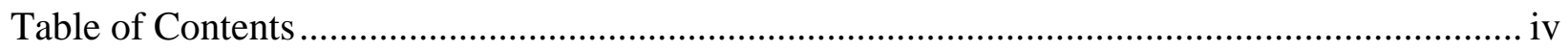

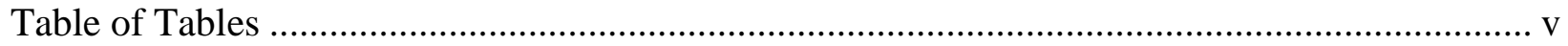

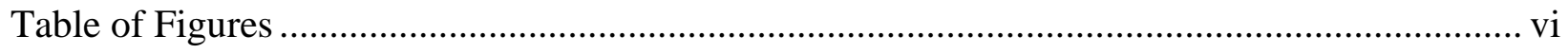

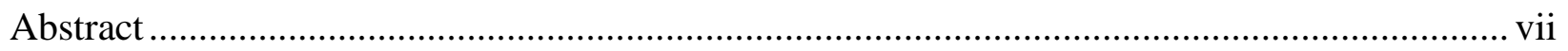

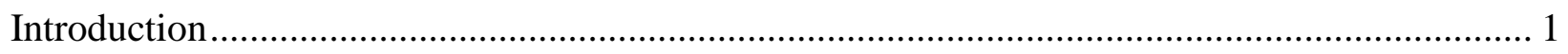

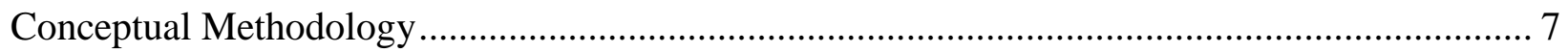

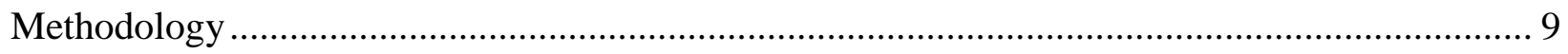

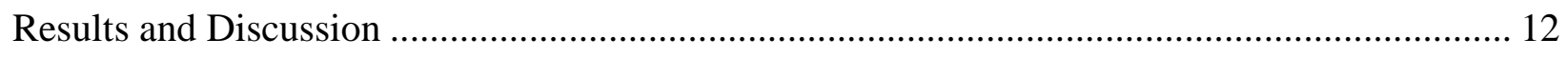

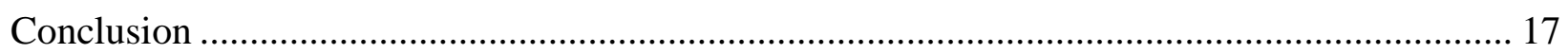

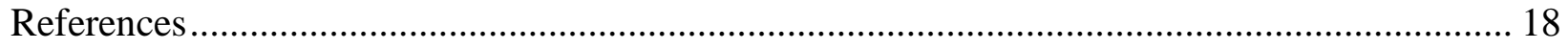

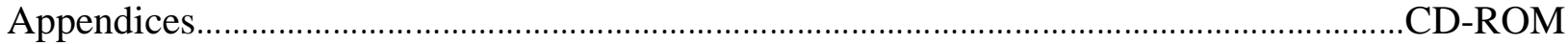




\section{Table of Tables}

Table 1: SIMA $1 \&$ SIMA 2 Water Transmissive Fractures

Table 2: SIMA 1 - Fracture Heads and Transmissivities

Table 3: SIMA 2 - Fracture Heads and Transmissivities .20

Table 4: BGAS 1, BGAS 2, \& BGAS 3 Water Transmissive Fractures

Table 5: BGAS 1 - Fracture Heads and Transmissivities

Table 6: BGAS 2 - Fracture Heads and Transmissivities

Table 7: BGAS 3 - Fracture Heads and Transmissivities .22 


\section{Table of Figures}

Figure 1: Conceptual Well Cross Section ..........................................................................23

Figure 2: Conceptual Well Cross Section Packer at Depth B .............................................24

Figure 3: Conceptual Well Cross Section Packer at Depth C..............................................25

Figure 4: Conceptual Well Cross Section Packer at Depth D ............................................26

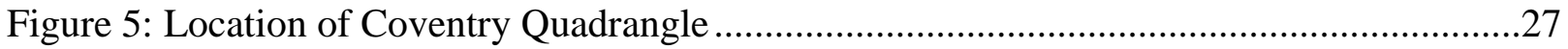

Figure 6: Generalized Bedrock Geologic Map of Coventry Quadrangle ...............................28

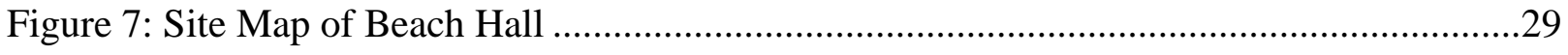

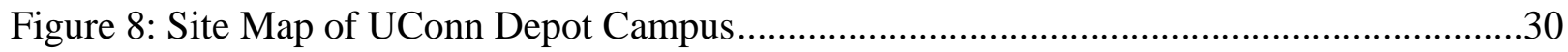

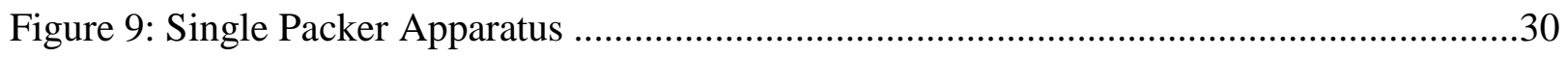

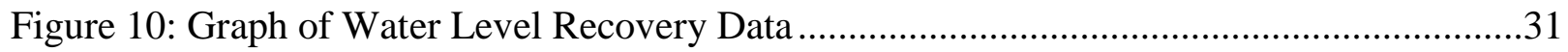

Figure 11: Type Curve Matching Water Level Displacement Data .......................................32

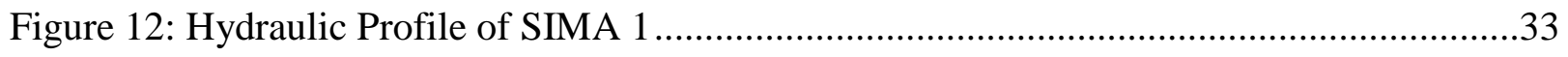

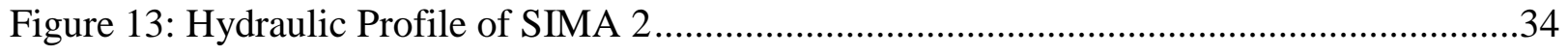

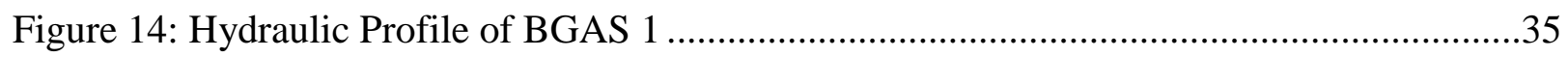

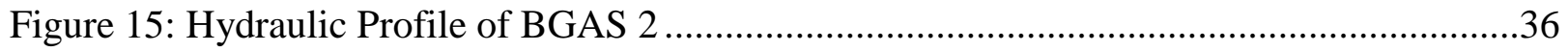

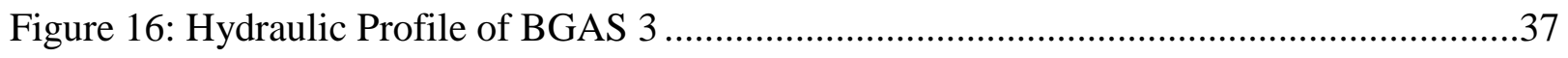

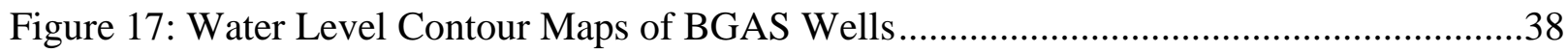




\begin{abstract}
The water levels and water quality obtained from open borehole wells in fractured bedrock are flow weighted averages that are a function of the hydraulic heads and transmissivities of water contributing fractures, which are rarely known. Without such knowledge using water levels and water quality data form fractured bedrock wells to assess contaminant conditions can be highly misleading. This study demonstrates a cost effective single packer fracture characterization method that can be used in fractured bedrock to determine the hydraulic heads and transmissivities of individual fracture zones. The method entails inflating a pipe plug to isolate sections of an open borehole at different depths and monitoring changes in water level with time. At each depth, the change in water level with time was used to determine the sum of fracture transmissivities above the packer and then to solve for individual fracture transmissivity. Steady state heads along with the transmissivities were used to determine fracture heads by solving for individual heads using the weighted average head equation. The method was tested in five wells in crystalline bedrock located at the University of Connecticut in Storrs. The wells had been previously logged with both conventional logging methods and the dissolved oxygen alteration method. The single packer head and transmissivity results were found to agree with borehole flow conditions determine by these other methods.
\end{abstract}




\section{Introduction}

Groundwater flow and contamination in fractured crystalline rock is often localized to a number of main fractures. The identification and properties of these main fractures are critical since they control the flow of groundwater as well as the transport of solutes in the subsurface (Le Borgne et al. 2007).

In a groundwater system, water elevation is a measure of energy known as hydraulic head, where flow is directed from a point of high hydraulic head to a point of low hydraulic head. In a fractured rock well, the water level in the well bore under ambient conditions is a weighted average of the intersecting fractures heads, weighted with respect to their transmissivity values as shown in Equation 1 (Sokol, 1963).

$$
h_{w}=\frac{(h 1 T 1+h 2 T 2+h 3 T 3)}{(T 1+T 2+T 3)}
$$

Where:

$$
\begin{aligned}
& \mathrm{h}_{\mathrm{w}}=\text { Well hydraulic head } \\
& \mathrm{h} 1=\text { Fracture } 1 \text { hydraulic head } \\
& \mathrm{h} 2=\text { Fracture } 2 \text { hydraulic head } \\
& \mathrm{h} 3=\text { Fracture } 3 \text { hydraulic head } \\
& \mathrm{T} 1=\text { Fracture } 1 \text { transmissivity } \\
& \mathrm{T} 2=\text { Fracture } 2 \text { transmissivity } \\
& \mathrm{T} 3=\text { Fracture } 3 \text { transmissivity }
\end{aligned}
$$

Most contaminant assessments of fractured rock wells are based on sampling water from spigots at a home, low flow or passive sampling of open boreholes, and open borehole water levels measurements. Estimating groundwater flow direction, rate, and contaminant concentration based on these types of sampling can be highly misleading owing to averaging effects (Metcalf and Robbins, 2014). By isolating discrete sections of the well for methods of characterization 
and sampling, the effects of an open borehole on hydraulic and chemical data are eliminated (Shapiro, 2001). As such, the development of a conceptual model of groundwater flow and solute transport in such a system requires each fracture (or fracture zone) hydraulic head to be characterized individually.

Advancements in borehole logging and tracer testing techniques have enabled researchers to comprehend the complex nature of groundwater flow and solute transport through fractures in the subsurface (Johnson et al., 2005). The United States Geological Survey (USGS) "Total Toolbox" is an approach most commonly used to characterizing groundwater flow in fractured rock (Haeni, 2000). This approach integrates geologic, hydrologic, and geochemical data with borehole-geophysical analysis. However, these methods can be expensive, time consuming, and technically challenging. Thus, they are generally only deployed when there is substantial funding available.

Johnson et al. (2005) conducted a study in cooperation with the U.S. Geological Survey and the University of Connecticut illustrating the application of the "Total Toolbox" approach for data accumulated from 1992-2002. A suite of methods were used to characterize the hydrogeology of a fractured-rock aquifer near a former landfill and chemical-waste disposal pit to determine head and transmissivity of individual fracture zones (Johnson et al., 2015). Utilizing the "Total Toobox" approach, the depth of discrete water contributing fracture zones were determined by borehole logging and heat pulse flow meter testing. The identified discrete fracture intervals of open boreholes were isolated using the $\mathrm{BAT}^{3}$ straddle-packer apparatus which can simultaneously obtain hydraulic properties and conduct fluid-withdrawal tests. The $\mathrm{BAT}^{3}$ system consists of a series of dual packers for isolating fracture zones connected with multi-channel tubing fitted with pressure transducers and pumps for obtaining samples from the 
isolated zones. However, the complexity of such a system creates limitations. To suspend and lower the system into position, a large drill rig is required, diminishing the ease of transportation and complicating the logistics of the study. In addition, depending on the transmissivity of the test interval, each test requires long periods of time to allow for the heads to equilibrate, further requiring the long-term availability of a drill rig throughout the investigation. The issue of cost becomes an integral part of the site investigations, where the application of such methods result in an extremely high cost owing to the time and equipment involved. Other problems associated with discrete-zone monitoring systems include periods of missing or unreliable data because of packer failure, leaking pressure lines, freezing water lines, failing pressure gages used to monitor the packer inflations, and overflowing water in individual continuous multi-channel tubing (Johnson et al., 2005).

Another study conducted by Le Borgne et al. (2007) compared different hydraulic measurement techniques in a fractured-rock aquifer in Britanny, France. The methods applied in this study included geophysical and imaging logs, single and cross-borehole flowmeter tests and single and double packer tests. To identify open and closed fractures intersecting the boreholes, geophysical logging and borehole imaging were utilized. The fractures interpreted from the geophysical logs were then hydraulically tested by performing single packer step drawdown tests and single borehole flowmeter tests to determine which fractures were significantly transmissive. Cross-borehole connectivity of transmissive fractures were interpreted using the following methodologies: 1. Projecting the intersection of transmissive fractures with other boreholes by the orientation determined from the geophysical logs; 2. Single packer hydraulic tests with pressure monitoring in adjacent wells; 3 . Cross-borehole flowmeter tests, tracking measurable changes in vertical flow in other boreholes; 4. Mutli-level pressure monitoring in observation 
wells during hydraulic testing (Le Borgne et al., 2007). The results highlighted the applications and limitations of each method. Analysis of multi-level drawdown data in observation wells and pumping wells allowed for an efficient characterization of fracture zone connectivity. When compared with flowmeter test results a consistency of connected flow zones was observed. Comparison of flowmeter and single packer tests conducted on adjacent boreholes also provided comparable results of connectivity. However, a limitation of the single packer technique was the inability to be applied to a screened borehole. Where the advantage of the flowmeter based method was that it does not require the use of a packer and can be used in a cased well. It was also found if multiple connections exist between boreholes, the distribution of connection fractures can be identified, but to determine exactly which fractures are connected the use of dual packers is required or a combination of a single packer in the pumping well and a flowmeter in the observation well. As illustrated, detailed characterization of fracture connectivity and flow paths in fractured rock is extremely difficult and requires complex methodologies.

Neuman (2005) discusses the challenges associated with quantifying flow and transport through fractured rock and emphasizes that hydrogeologic characterization of fractured rock aquifers requires accounting for highly erratic heterogeneity, directional dependence, dual or multicomponent nature and multiscale behavior. Parker et al. (2012) provide an approach for acquisition of data for individual fractures and fracture networks, referred to as the discrete fracture network (DFN) approach. The DFN approach involves acquiring field and laboratory data from rock cores, including core analysis of contaminant distribution and physical, chemical, and microbial properties of the matrix, and borehole tests focused on the nature of the fracture system. Although the DFN approach had been developed specifically for sedimentary rock, it is relative to all rock types and is typically used in conjunction with other methods of borehole data 
acquisitions (e.g., acoustic and/or optical image logs (ATV/OTV), gamma logs, temperature logging, and liner profiling). The collection of many different types of data is optimal for fractured rock characterization, however a combined approach can soon become expensive. The rock coring drilling method required for the DFN approach and the laboratory core analysis can significantly increase the cost for investigation.

Flexible Liner Underground Technologies Limited (FLUTe ${ }^{\mathrm{TM}}$ ) have developed many different flexible liners made of watertight, nylon fabric for high resolution subsurface characterization. The motivation for the use of flexible liners to seal holes came from the recognition of the need to minimize cross contamination at sites in fractured rock. As described earlier, boreholes in fractured rock connect fractures with higher hydraulic head to fractures with lower head in the same hole, inducing vertical cross flow and hydraulic mixing between fractures. When contaminants are introduced in such a system, connections between fractures can worsen the degree of contamination at a site and confuse the hydrochemical conditions being investigated (Keller et al., 2013). A method which utilizes the use of FLUTe ${ }^{\mathrm{TM}}$ borehole liners for continuous transmissivity profiling in fractured rock was developed by Keller et al. (2013). This method involves filling the flexible borehole liner with water to create a constant driving head to evert (reverse of invert) the liner down the borehole so that the liner pushes the borehole water out into transmissive fractures or other permeable features. As the everting liner passes and seals each permeable feature, changes in the liner velocity indicate the position of each feature and an estimate of transmissivity is calculated using the Thiem equation for steady radial flow (Keller et al., 2013). Once at the bottom of the borehole, the liner acts as a seal to prevent borehole cross connections between fractures at different depths and removal of the liner can be used for other investigative purposes. The transmissivity values determined using the linear 
profiling method was found to be comparable to the values obtained by conventional straddle packer tests (Keller et al., 2013). Keller et al. (2013) found this method to be an effective and efficient for scanning entire boreholes for transmissive features, where profiling commonly takes only a few hours.

FLUTe $^{\mathrm{TM}}$ flexible liner method (linear profiling) was also utilized in a study conducted by Quinn et al. (2015) in densely fractured rock boreholes. Typical fractured rock investigations require time consuming borehole interval testing; however, this study highlights the combined use of high resolution hydraulic tests using straddle packers and the FLUTe ${ }^{\mathrm{TM}}$ flexible liner method to be efficient methods for determining the vertical distribution of transmissivity along entire boreholes. This combined approach of liner profiling and straddle packer testing is a refinement of the DFN approach described earlier by Parker et al. (2012), which utilizes data generated from the DFN approach to maximize efficiency of collecting depth-discrete hydraulic data representative of the entire borehole. Quinn et al. (2015) found that because of the timeconsuming aspect of this multiple test method, to maximize efficiency, straddle packer testing should be focused on priority zones selected by prior borehole data, with emphasis on the liner transmissivity profile. The methods outlined in this study have different investigative values and when used in combination can diminish their individual deficiencies.

As cited above the main drawbacks of previous methods for fractured bedrock well characterization are cost and complexity. The main objective of this research is the development of a low-cost, simplified method for characterizing the hydraulic head and transmissivity of water contributing fractures that intersect wells in fractured crystalline bedrock. 


\section{Conceptual Methodology}

Figure 1 shows an ideal cross section of a well in fractured crystalline bedrock that is intersected by two fractures that supply water to the well and one discharging fracture. Under static conditions the water level in the well, $\mathrm{h}_{\mathrm{w}}$, is a weighted average as shown in Equation 1. In addition, when more than one fracture intersects a well, the well's total transmissivity $\mathrm{T}($ total) is equal to the sum of all the fracture transmissivities (Equation 2).

$$
T(\text { total })=T 1+T 2+T 3
$$

A single inflatable plumber's test ball plug is then lowered down the well to depth B. A pressure transducer is also lowered and positioned at depth A. The packer is then inflated to isolate fracture 1, accept for a small change due to packer expansion, the water level will rise since this is an inflowing fracture to h1, as seen in Figure 2. The rate of water level rise can be analyzed using a slug test solution for determining the transmissivity of fracture $1, \mathrm{~T} 1$. The packer is then deflated, the water level allowed to recover to the static level and then the packer is positioned at the next test depth.

At depth $\mathrm{C}$, after the packer is inflated, the water level will rise to a weighted average head h(1-2) determined by Equation 3, as seen in Figure 3.

$$
h(1-2)=\frac{(h 1 T 1+h 2 T 2)}{(T 1+T 2)}
$$

Where:

$\mathrm{h}(1-2)=$ Weighted average hydraulic head of fractures 1 and 2 
The rate of rise can be analyzed as a slug test to determine T(1-2). Given T1, T2 can simply be found by solving Equation 4. Given T2, Equation 3 can be rearranged to Equation 5 and solved for h2.

$$
T 2=T(1-2)-T 1
$$

Where:

$\mathrm{T}(1-2)=$ Transmissivity of combined Fractures 1 and 2

$$
h 2=\frac{((h(1-2) *(T 1+T 2)-(h 1 T 1))}{T 2}
$$

At depth D, after the packer is inflated the water level should be equal to the static level, as seen in Figure 4. Hence Equation 1 applies. A full well slug in test is then initiated raising the head. The test is analyzed like the previous tests to determine $\mathrm{T}$ (total). The transmissivity of facture 3, T3, is determined using Equation 6. Given T3, Equation 1 can be rearranged to Equation 7 to determine h3.

$$
T 3=T(\text { total })-T 1-T 2
$$

Where:

$$
\begin{aligned}
& \mathrm{T}(\text { total })=\text { Total well's transmissivity } \\
& \qquad h 3=\frac{h(w) *(T 1+T 2+T 3)-(h 1 T 1)-(h 2 T 2)}{T 3}
\end{aligned}
$$




\section{Methodology}

Study Sites

The above conceptual methodology was applied at two study sites at the University of Connecticut in Storrs. Figure 5 outlines the Coventry Quadrangle, located in northeastern Connecticut, where the two test sites are located. The University of Connecticut in Storrs is in the Eastern Highlands region of Connecticut consisting mostly of fractured metamorphic rocks. The two study sites are underlain by Hebron Gneiss (Figure 6). The formation is described as Ordovician aged, interlayered dark-grey, medium to coarse grained schist and greenish-grey fine to medium grained cal-silicate gneissic rock (Rogers, 1985). The bedrock at both sites is overlain by glacial till and fill.

Beach Hall-SIMA $1 \&$ SIMA 2

The location of the two bedrock wells tested on campus at Beach Hall, SIMA 1 and SIMA 2, are shown on Figure 7. The wells are located on top of a hill that slopes eastward and are spaced $27 \mathrm{~m}$ apart. Both wells were drilled to $91 \mathrm{~m}$ using compressed-air percussion. The overburden is meters thick and consists of fill overlying glacial till. The wells are constructed of 9 meters of steel casing having a diameter of $15.24 \mathrm{~cm}$ that extends from $0.5 \mathrm{~m}$ above the surface to about 2.5 meters into rock. Below the casing the wells are an open borehole. Completion reports for SIMA 1 and SIMA 2 are included in Appendix A.

\section{UConn Depot Campus}

Three bedrock wells (BGAS-1, BGAS-2, and BGAS-3) located at the University of Connecticut Depot Campus in Storrs were tested. Their locations are shown on Figure 8. BGAS 1, BGAS 2, and BGAS 3 are 73.76, 135.58, and $76.80 \mathrm{~m}$ in depth, respectively. Wells were installed using the compressed-air percussion drilling method and are cased down to bedrock 
which lies $4.6 \mathrm{~m}$ below the glacial till overburden. The diameter of the well casing is $15.2 \mathrm{~cm}$. Completion reports for the wells are included in Appendix A.

\section{Field Methods}

The results of borehole geophysical investigations (Cagle, 2005; Phillips, 2016) and the application of the dissolved oxygen alteration method (Chlebica and Robbins, 2013; Vitale, 2016) conducted previously on the test wells were reviewed to determine: (1) the depths of water transmissive fractures; (2) the direction of borehole flow; and (3) the relative transmissivities.

Discrete fracture intervals of the selected boreholes were isolated using a single Cherne® Multi-Sized Test-Ball, Part Number: 275048, 4" - 6”, Cost: \$140.00 USD (Figure 9). The test ball was weighted and connected to a pressure line (Flexzilla® Air Hose, Cost: $\$ 40.00$ USD). A metal pipe was connected to the pressure line to add weight to the test ball to assist during descent. At the surface, the line was connected to a regulator of a compressed air tank. An Instrument Northwest, Inc. (AquiStar®PT2X) or Geoprobe (Model Number: 19345) pressure transducer was inserted in the well above the upper fracture to measure head changes with time following packer inflation. Data loggers were programmed to measure and record water levels every minute.

The packer was slightly inflated to 10 psi to help facilitate lowering it down the borehole. Once at the required depth, the packer was inflated with compressed air, and left in place until the water level rose or fell to a steady state head. The pressure required to fully seal the borehole was calculated using Equation 8.

$$
\text { Inflation Pressure }=\left(D_{p}-D T W\right) * C+P_{p}
$$

Where:

$\mathrm{D}_{\mathrm{p}}=$ Depth of packer $(\mathrm{ft})$

$$
\text { DTW }=\text { Depth to water }(\mathrm{ft})
$$


$\mathrm{C}=$ Constant that converts height of water to psi (0.43)

$\mathrm{P}_{\mathrm{p}}=$ Packer Inflation Pressure (30 psi)

Periodically the pressure in the packer line was monitored using a high sensitivity gauge connected to the regulator to verify the packer maintained a seal. Zones of lower transmissivity require longer periods of time to equilibrate where the packer was sealed in place overnight. Once the pressure readings reached steady state, the packer was deflated and lowered to another test interval. After each identified fracture zone was tested, a slug-in test was conducted without the packer in the well to determine the wellbore's total transmissivity. This method involves the addition of a slug of water to the wellbore, raising the head $\sim 1.52 \mathrm{~m}$., and monitoring the fall of the water level with time.

\section{Head and Transmissivity Analysis}

The recovery data recorded on the pressure transducer for each test was analyzed to determine the stable hydraulic head for the depth interval above the packer. This was conducted by plotting the water pressure vs. time. An example of the water displacement plot is shown in Figure 10. The water displacement data was subtracted (if pressure rose) or added (if pressure declined) from the initial pressure reading to obtain the differential head of the zone above the packer. The steady state differential head was added or subtracted from the well head before packer inflation to determine the head of the fracture zone. The heads were then processed using the approach discussed in the conceptual model. Surface elevations that were not previously recorded were surveyed and measured to the nearest 0.01 foot, referenced to mean sea level. Depth to water readings were relative to ground surface and were adjusted by subtracting the casing height above ground surface.

Using the computer program AQTESOLV $V^{T M}$, fracture transmissivity was determined for each hydraulically active fracture. Using the solution by Cooper-Bredehoeft-Papadopulos (1967) 
for non-leaky confined aquifers, the analysis involved matching a type-curve to water-level displacement data for an overdamped slug test (Figure 11).

\section{Results and Discussion}

Beach Hall - SIMA 1 \& SIMA 2

Table 1 lists the water transmissive fractures identified in SIMA 1 and SIMA 2 by previous studies conducted by Cagle (2005) and Vitale (2017). The televiewer logs were used to determine the orientation of fractures and foliation. In general, the fractures in SIMA 1 have a relatively shallow dip angle with a north-northeasterly azimuth or are orientated relatively horizontal (Cagle, 2005). However, one large fracture located at $39 \mathrm{~m}$ has a dip angle of 79 degrees southward and potentially connects to the shallow zone of fractures from $10-42 \mathrm{~m}$ outside of the well boring.

To determine the hydraulic heads and transmissivities of the fractures, the packer was placed below the fracture depths listed in Table for both SIMA 1 and SIMA 2. Tables 2 and 3 are the corresponding results of the fracture head and transmissivity determinations in both wells. A hydraulic profile of SIMA 1, shown in Figure 12, illustrates the fracture head elevations relative to the static well head elevation. The static well head elevation, $\mathrm{h}_{\mathrm{w}}$, of SIMA 1 was $184.34 \mathrm{~m}$. The three test zones showed increases in head in response to being sealed off from the open borehole. The vertical orientation of the $41 \mathrm{~m}$ fracture likely connects with the $16.5 \mathrm{~m}$ and 10.9 $\mathrm{m}$ fractures outside the borehole, averaging the fracture heads, which is indicated by the relatively small changes in head between them. The $10.9 \mathrm{~m}, 16.5 \mathrm{~m}$, and $41 \mathrm{~m}$ fractures have relative heads of $+0.20 \mathrm{~m},+0.49 \mathrm{~m}$, and $+0.30 \mathrm{~m}$ from the static well head $\left(\mathrm{h}_{\mathrm{w}}\right)$ respectively. All of these were inflowing fractures which is consistent with observations by Cagle (2005) and 
Chlebica and Robbins (2013). Furthermore, the DO profiles show, under ambient conditions, water flows down the borehole and out of a fracture near the bottom of the well. The deepest fracture had the lowest head which was consistent with this flow pattern. The total well's transmissivity from a slug test indicated the presence of a highly transmissive fracture below the tested intervals. The heat pulse flowmeter results from Cagle (2005) verified the presence of a highly transmissive fracture at a depth of $85 \mathrm{~m}$. Table 2 shows SIMA 1's fracture transmissivities increasing with depth, with the most transmissive fracture outflowing at $85 \mathrm{~m}$, largely influencing the static well head.

Figure 13 illustrates a hydraulic profile of SIMA 2. Most of the water transmissive fractures in SIMA 2 have a shallow dip to the north-northwest that parallels the orientation of the foliation, except for a $45 \mathrm{~m}$ deep fracture which has a dip angle of 61 degrees and a southsouthwestward azimuth (Cagle, 2005). The deepest and shallower fractures exhibit heads that show they were inflowing. The high angle fracture at $45 \mathrm{~m}$ was outflowing. Once sealed at 17.3 $\mathrm{m}$, the water level in SIMA 2 rose $4.2 \mathrm{~m}$. In contrast, the $45 \mathrm{~m}$ outflowing fracture in SIMA 2 had a relative head of $-8.5 \mathrm{~m}$ from static $h_{w}$. The large head differences amongst the fractures in this well may be related to their dip. The steeply dipping fracture is likely recharged from the overburden close to the well location but discharges to the overburden further downhill than the sub-horizontal fractures resulting in a lower head. Given the orientation of the sub-vertical fractures, they would likely be recharged further uphill than the steeply dipping fracture resulting in a higher head. The static well head of SIMA 2 had an elevation of $179.88 \mathrm{~m}$, which resulted in a head difference of 4.46 m from SIMA 1. These wells are known to be hydraulically connected based on observed drawdown in pumping tests (Cagle, 2005) and studies using the dissolved oxygen alteration method (Vitale and Robbins, 2015). The latter showed that the fracture at 16.5 
$\mathrm{m}$ in SIMA 1 was connected to the $13.1 \mathrm{~m}$ fracture in SIMA 2. The wells are spaced $27 \mathrm{~m}$ apart. Using the $h_{w}$ elevations, the apparent hydraulic gradient between SIMA 1 and SIMA 2 is $0.28 \mathrm{~m}$. However, the calculated apparent gradient based on the heads in the interconnected fractures was only $0.05 \mathrm{~m}$, indicating a significant difference in flow rate.

\section{UConn Depot Campus, BGAS 1, BGAS 2, BGAS 3}

Table 4 lists the transmissive fractures identified in BGAS 1, BGAS 2, and BGAS 3 based on recent geophysical borehole logging (Phillips, 2016) and tracer studies (Brainerd and Robbins, 2004; Vitale, 2016). Figure 14 illustrates a hydraulic profile of BGAS 1 and Table 5 lists corresponding fracture hydraulic head and transmissivity values. The inflowing fractures were identified at depths of $9.1 \mathrm{~m}, 16.8 \mathrm{~m}, 30.5 \mathrm{~m}$ and one outflowing fracture at a depth of 39.6 $\mathrm{m}$. The obtained head values and the full well's total transmissivity from the slug test indicated the presence of an outflowing fracture at a depth below the $30.5 \mathrm{~m}$ fracture. Dissolved oxygen profiles (Vitale, 2016) of BGAS 1 suggested a fracture is located at $73.1 \mathrm{~m}$.

Based on the calculated fracture heads, under ambient flow conditions flow direction in BGAS 1 was downward from $9.1 \mathrm{~m}$ to $39.6 \mathrm{~m}$, which agrees with the dissolved oxygen profiles (Vitale, 2016). The $30.5 \mathrm{~m}$ fracture had a nearly identical head elevation as the static well head, $\mathrm{h}_{\mathrm{w}}$ and, when compared to the other intersecting fractures, the $30.48 \mathrm{~m}$ fracture had a significantly higher transmissivity $\left(1.1 \times 10^{-4} \mathrm{~m}^{2} / \mathrm{sec}\right)$. The static well head was weighted towards the head in this fracture. Any fluctuations in the static water level of only $.01 \mathrm{~m}$ would determine whether the $30.5 \mathrm{~m}$ fracture is inflowing or outflowing.

Table 6 lists the transmissive fractures identified with their corresponding head elevations and transmissivities in BGAS 2. Figure 15 illustrates the hydraulic profile of BGAS 2. Review of 
dissolved oxygen alteration method profiles (Vitale, 2016) suggest that water in the open borehole under ambient conditions is stagnant. However, two inflowing fractures were identified at depths of $15.2 \mathrm{~m}$ and $33.5 \mathrm{~m}$ from DO tracer profiles under pumping conditions (Vitale, 2016) which were isolated and sealed with the packer. The obtained head recovery data from the two fractures resulted in minimal head change from the static water level elevation, but could not be used to accurately obtain individual fracture transmissivity.

In addition, a total well transmissivity value $\left(2.8 \times 10^{-4} \mathrm{~m}^{2} / \mathrm{sec}\right)$ obtained from the slug test confirmed the presence of a highly transmissive fracture at depth. DO profiles (Vitale, 2016) revealed the presence of fracture at a depth of $132.6 \mathrm{~m}$, depicted by a large dilution in dissolved oxygen. However, the $132.6 \mathrm{~m}$ fracture was suggested to be an inflowing fracture under ambient conditions, where the calculated head values imply a highly transmissive outflowing fracture somewhere at a depth below $33.5 \mathrm{~m}$.

Table 7 lists the transmissive fractures identified with their corresponding head elevations and transmissivities in BGAS 3. Figure 16 illustrates the hydraulic profile of BGAS 3 . Two water bearing fractures intersecting the boring at depths of $9.1 \mathrm{~m}$ and $30.5 \mathrm{~m}$ were identified. When the well was sealed below the $30.5 \mathrm{~m}$ fracture, the water level dropped $0.39 \mathrm{~m}$ indicating an outflowing fracture with a relative head of $-0.78 \mathrm{~m}$ from static $\mathrm{h}_{\mathrm{w}}$, the lowest fracture head intersecting the boring.

A full well slug test of BGAS 3 suggested a highly transmissive fracture at a depth below the tested intervals and the DO profile (Vitale 2016) identified a $73.1 \mathrm{~m}$ fracture seemed to be present at the bottom of the boring, approximately at $73.1 \mathrm{~m}$. The calculated head of the $73.1 \mathrm{~m}$ fracture resulted in relative head to static $h_{w}$ of $-0.07 \mathrm{~m}$. Any minor change in static water level could change this fracture to either an inflowing or outflowing fracture. 
Interconnected Fractures (BGAS 1, BGAS 2, BGAS 3)

Obtaining individual fracture heads with this method allows for interpretations of connected fractures between wells. Connections between fractures can be interpreted by similar head elevations and orientations. Examination of geophysical logs reveals that transmissive fractures in all three BGAS wells have horizontal or sub-horizontal orientations. Pumping tests show the wells were interconnected. The fractures at depths of $30.5 \mathrm{~m}, 33.5 \mathrm{~m}$, and $30.5 \mathrm{~m}$ in BGAS 1, BGAS 2, and BGAS 3, respectively have similar head elevations (within $0.97 \mathrm{~m}$ ) and are likely interconnected.

Figure 17 compares the hydraulic gradient of static well head elevations, $h_{w}$, from all three wells to the hydraulic gradient of the assumed connected fractures at a depth of $\sim 30 \mathrm{~m}$. The topography at the site location is relatively flat and therefore, the hydraulic gradient cannot be relatively surmised by the slope. Using the static well heads of each well to determine ground water flow direction resulted in an opposite flow direction than that determined using the $\sim 30 \mathrm{~m}$ fracture head elevations from each well. This demonstrates how relying on static water level elevations of wells intersecting fractured bedrock to assess flow directions and rates could lead to costly errors due to the hydraulic complexities of fractured bedrock flow and contaminant transport.

\section{Limitations \& Possible Sources of Error}

Since each fracture hydraulic head was calculated from the results of the previous test interval, the fluctuation of static water levels from day to day influence the calculations of fracture head and transmissivity. Hydraulic heads vary in response to recharge, pumping, evapotranspiration, barometric pressure, and tidal forces (Johnson et al., 2005). However, since each depth interval in this study were run for a maximum of roughly 24 hours, only small 
variations in static water level were observed. By using an average of the static water levels between testing intervals in calculations this effect can be diminished.

Another potential source of error in this method is packer failure and pressure system leakage. Deep fractures require additional air hosing for the packer to be inflated at such depths; therefore, adding more connections could be a source for air leakages. Packer inflations were checked and water levels monitored during the testing interval to ensure a full seal.

For fractures with head elevations nearly identical to the static well head elevation, the water level displacement was so minimal and the data would not be used to accurately determine the transmissivity of the fracture or fracture interval. In order to do so different configurations of the packer apparatus would be required. In this case, it is suggested to seal off a fracture or interval of fractures and conduct a slug test while the borehole is sealed at a discrete depth to obtain a more accurate fracture transmissivity.

\section{Conclusion}

This study demonstrates that a cost-effective, simplified single packer fracture characterization method can be used to confirm the presence and depths of water transmissive fracture zones and to determine fracture transmissivity and hydraulic head. Used in conjunction with other methods to locate transmissive fractures, such as the dissolved oxygen alteration method, the single packer approach can provide a more cost effective means of transmissive fracture characterization over other available approaches. Although not without its limitations, as demonstrated here, application of this approach can help eliminate the misleading effects of using weighted average hydraulic head determinations in open borehole wells in assessing groundwater flow and solute transport. 


\section{References}

Brainerd, R.J., and G.A. Robbins. 2004. A Tracer Dilution Method for Fracture Characterization in Bedrock Wells. Ground Water 42, No. 5: 774-780.

Cagle, Matthew B., "Fracture Hydrogeology of Two Wells in Crystalline Bedrock Located in a Glacial Upland in Connecticut" (2005). Master's Thesis.

Chlebica, Dariusz, "Modifying Borehole Dissolved Oxygen Levels as a Tool in Deciphering Fracture Flow Conditions" (2013). Master's Theses.

Chlebica, D.W. and G.A. Robbins. 2013. Altering Dissolved Oxygen to Determine Flow Conditions in Fractured Bedrock Wells. Groundwater Monitoring and Remediation 33, no. 4:100-107.

Cooper, H.H., J.D. Bredehoeft and S.S. Papadopulos, 1967. Response of a finite-diameter well to an instantaneous charge of water, Water Resources Research, vol. 3, no. 1, pp. 263-269.

Haeni, F.P., 2000, Use of Geophysical Tool Box to Characterize Ground-Water Flow in Fractured-Rock, presented at the EPA Fractured Rock Workshop, Providence, RI, November 8-9, 2000 (http://water.usgs.gov/ogw/bgas/presentations/epafrcrkcon.pdf).

Johnson, C.D., Kochiss, C.K., and Dawson, C.B., Use of discrete-zone monitoring systems for hydraulic characterization of a fractured-rock aquifer at the University of Connecticut landfill, Storrs, Connecticut, 1999 to 2002: U.S. Geological Survey, Water-Resources Investigations Report 03-4338, 105 p.

Keller, C., Cherry, J.A., Parker, B.L., 2013. New method for continuous transmissivity profiling in fractured rock. Groundwater. http://dx.doi.org/10.1111/ gwat.12064.

Le Borgne, L., O. Bour, M.S. Riley, P. Gouze, P.A. Pezard, A. Belghoul, G. Lods, R. Le Provost, R.B. Greswell, P.A. Ellis, E. Isakov, and B.J. Last. 2007. Comparison of alternative methodologies for identifying and characterizing preferential flow paths in heterogeneous aquifers. Journal of Hydrology 345, no. 3-4: 134-148.

Metcalf, M. J. and Robbins, G.A., 2014, Evaluating Groundwater Sustainability for Fractured Crystalline Bedrock. Water Science and Technology: Water Supply, (early pub available online at doi:10.2166/ws.2013/179)

Neuman, S. P. (2005). Trends, prospects and challenges in quantifying flow and transport through fractured rocks. Hydrogeology Journal, 13(1), 124-147. DOI: 10.1007/s10040004-0397-2

Paillet, F.L. 2000. A field technique for estimating aquifer parameters using flow log data. Ground Water 38, no. 4: 520-521. 
Parker, B.L., J.A. Cherry, and S.W. Chapman. 2012. Discrete fracture network approach for studying contamination in fractured rock. AQUAMundi: Journal of Water Science 60, no. 52: $101-116$.

Phillips, Stephanie. Comparison of Flow Logging Methods at a Fractured Rock Site, Storrs, Connecticut. (2017) University of Connecticut. Masters Thesis.

Quinn P., J.A. Cherry, and B. L. Parker. 2015. Combined use of straddle packer testing and FLUTe profiling for hydraulic testing in fractured rock boreholes, Journal of Hydrology., $524,439-454$.

Rogers, J. 1985, Bedrock Geological Map of Connecticut: Connecticut Geological and Natural History Survey, in cooperation with U.S. Geological Survey, scale 1:125,000.

Sernoffsky R., Robbins G. and Mondazzi R. Use of the In Situ, Inc. MP Troll 9000 to Locate Fractures Contributing to Ground Water Flow in Bedrock Wells. 2004. U.S. Geological Survey.

Shapiro, A.M. 2001. Characterizing Ground-Water Chemistry and Hydraulic Properties of Fractured Rock Aquifers Using the Multifunction Bedrock Aquifer Transportable Testing Tool (BAT3): U.S. Geological Survey Fact Sheet FS-075- 01, 4 p.

Sokol, Daniel. 1963. Positions and Fluctuations of Water Level in Wells Perforated in More Than One Aquifer. Journal of Geophysical Research 68, no. 4: 1079-1080.

Vitale, S and Robbins, G. A., 2015, Using Dissolved Oxygen Alteration to Identify Connecting Transmissive Fractures and Determine Vertical Flow Velocity in Crystalline Bedrock Wells, GSA Annual Meeting, November 1, Baltimore, Maryland.

Vitale, Sarah A., Advanced Applications of the Dissolved Oxygen Alteration Method (2017). University of Connecticut. Doctoral Dissertation. 
SIMA 1 and SIMA 2:

Table 1: Water Transmissive Fractures Identified in Geophysical Borehole Logs (Cagle, 2005) and DO Alteration Profiles (Chlebica and Robbins, 2013)

\begin{tabular}{cc}
\hline SIMA 1 & SIMA 2 \\
Fracture Depth (m) & Fracture Depth (m) \\
\hline 10.9 & 10.6 \\
16.5 & 12.8 \\
$39.3-41.8$ & 17.3 \\
85.9 & $44.1-45.4$ \\
- & 75.5 \\
\hline
\end{tabular}

Table 2: SIMA 1 - Fracture Hydraulic Heads and Transmissivities

\begin{tabular}{ccc}
\hline $\begin{array}{c}\text { Fracture Depth } \\
(\mathbf{m})\end{array}$ & $\begin{array}{c}\text { Hydraulic Head } \\
\text { Elevation }(\mathbf{m})\end{array}$ & Transmissivity $\left(\mathbf{m}^{2} / \mathbf{s e c}\right)$ \\
\hline 10.9 & 184.54 & $8.1 \times 10^{-7}$ \\
16.5 & 184.83 & $3.1 \times 10^{-6}$ \\
$39.3-41.8$ & 184.64 & $5.7 \times 10^{-6}$ \\
85.9 & 184.03 & $6.8 \times 10^{-6}$ \\
Total Well & 184.34 & $1.6 \times 10^{.5}$ \\
\hline
\end{tabular}

Table 3: SIMA 2 - Fracture Hydraulic Heads and Transmissivities

\begin{tabular}{ccc}
\hline $\begin{array}{c}\text { Fracture Depth } \\
(\mathbf{m})\end{array}$ & $\begin{array}{c}\text { Hydraulic Head } \\
\text { Elevation }(\mathbf{m})\end{array}$ & Transmissivity $\left(\mathbf{m}^{2} / \mathbf{s e c}\right)$ \\
\hline 10.6 & 184.16 & $3.1 \times 10^{-7}$ \\
12.8 & 183.47 & $1.8 \times 10^{-7}$ \\
17.3 & 184.3 & $5.7 \times 10^{-7}$ \\
44.5 & 171.38 & $3.1 \times 10^{-7}$ \\
75.5 & 180.88 & $1.1 \times 10^{-5}$ \\
Total Well & 179.88 & $5.1 \times 10^{-5}$ \\
\hline
\end{tabular}


$B G A S$ 1, BGAS 2, BGAS 3:

Table 4: Water Transmissive Fractures Identified by Geophysical Borehole Logs (Phillips, 2016) and Dissolved Oxygen Alteration Profiles (Vitale, 2016)

\begin{tabular}{ccc}
\hline BGAS 1 & BGAS 2 & BGAS 3 \\
Fracture Depth (m) & Fracture Depth (m) & Fracture Depth (m) \\
\hline 9.1 & 15.2 & 9.1 \\
16.8 & 33.5 & 30.5 \\
30.5 & - & 73.2 \\
39.6 & - & - \\
\hline
\end{tabular}

Table 5: BGAS 1 - Fracture Hydraulic Heads and Transmissivities

\begin{tabular}{ccc}
\hline $\begin{array}{c}\text { Fracture Depth } \\
(\mathbf{m})\end{array}$ & $\begin{array}{c}\text { Hydraulic Head } \\
\text { Elevation }(\mathbf{m})\end{array}$ & $\begin{array}{c}\text { Transmissivity } \\
\left(\mathbf{m}^{2} / \mathbf{s e c}\right)\end{array}$ \\
\hline 9.1 & 147.22 & $6.8 \times 10^{-7}$ \\
15.2 & 148.54 & $5.4 \times 10^{-7}$ \\
30.5 & 146.07 & $1.1 \times 10^{-4}$ \\
39.6 & 145.34 & $3.8 \times 10^{-5}$ \\
Total Well & 146.08 & $1.5 \times 10^{-4}$ \\
\hline
\end{tabular}

Table 6: BGAS 2 - Fracture Hydraulic Heads and Transmissivities

\begin{tabular}{ccc}
\hline $\begin{array}{c}\text { Fracture Depth } \\
(\mathbf{m})\end{array}$ & $\begin{array}{c}\text { Fracture Head } \\
\text { Elevation }(\mathbf{m})\end{array}$ & $\begin{array}{c}\text { Transmissivity } \\
\left(\mathbf{m}^{2} / \mathbf{s e c}\right)\end{array}$ \\
\hline 15.2 & 145.50 & $\mathbf{? ?}$ \\
33.5 & 145.55 & $\mathbf{? ?}$ \\
Total Well & 145.37 & $2.8 \times 10^{-4}$ \\
\hline
\end{tabular}


Table 7: BGAS 3 - Fracture Hydraulic Heads and Transmissivities

\begin{tabular}{ccc}
\hline $\begin{array}{c}\text { Fracture Depth } \\
(\mathbf{m})\end{array}$ & $\begin{array}{c}\text { Hydraulic Head } \\
\text { Elevations }(\mathbf{m})\end{array}$ & $\begin{array}{c}\text { Transmissivity } \\
\left(\mathbf{m}^{2} / \mathbf{s e c}\right)\end{array}$ \\
\hline 9.1 & 147.24 & $3.5 \times 10^{-7}$ \\
30.5 & 145.1 & $1.6 \times 10^{-6}$ \\
73.2 & 145.81 & $4.9 \times 10^{-4}$ \\
Total Well & 145.88 & $4.8 \times 10^{-4}$ \\
\hline
\end{tabular}




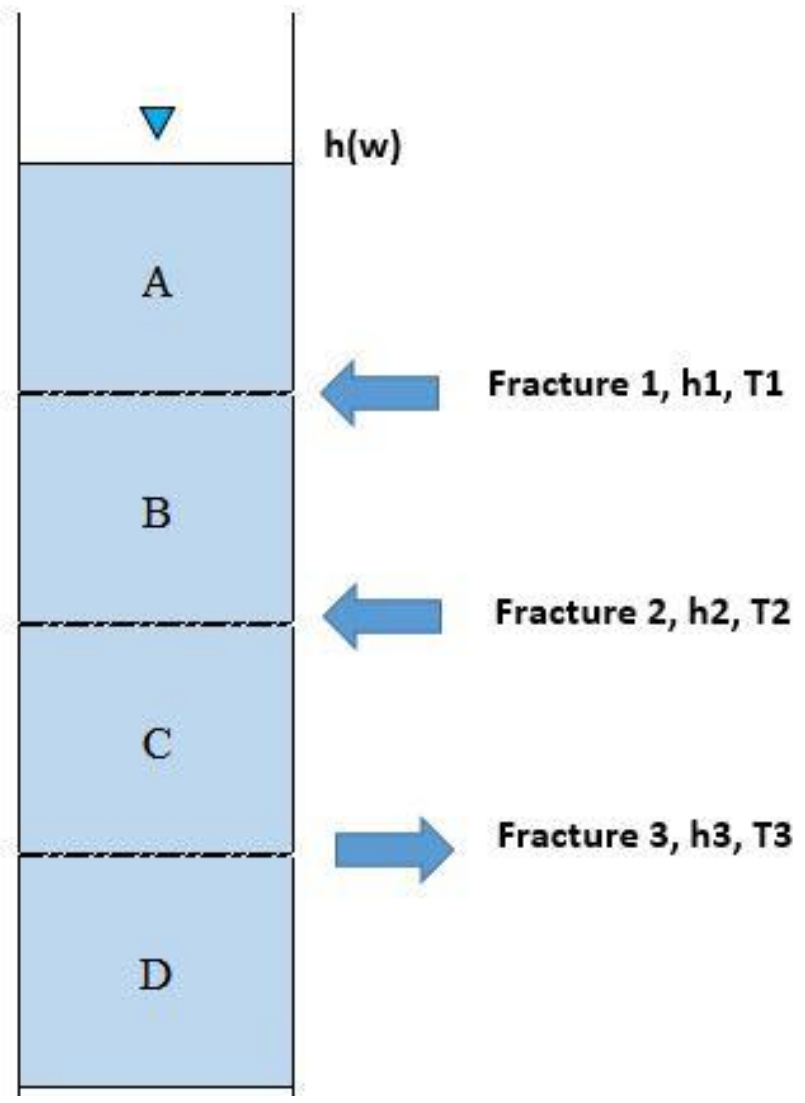

Figure 1: Cross section of well showing two inflowing fractures and one outflowing fracture, $\mathrm{T}$ $=$ transmissivity, $\mathrm{h}=$ fracture head, letters are depths where the packer is inflated. The water level of the well, $h(w)$, indicates static conditions. 


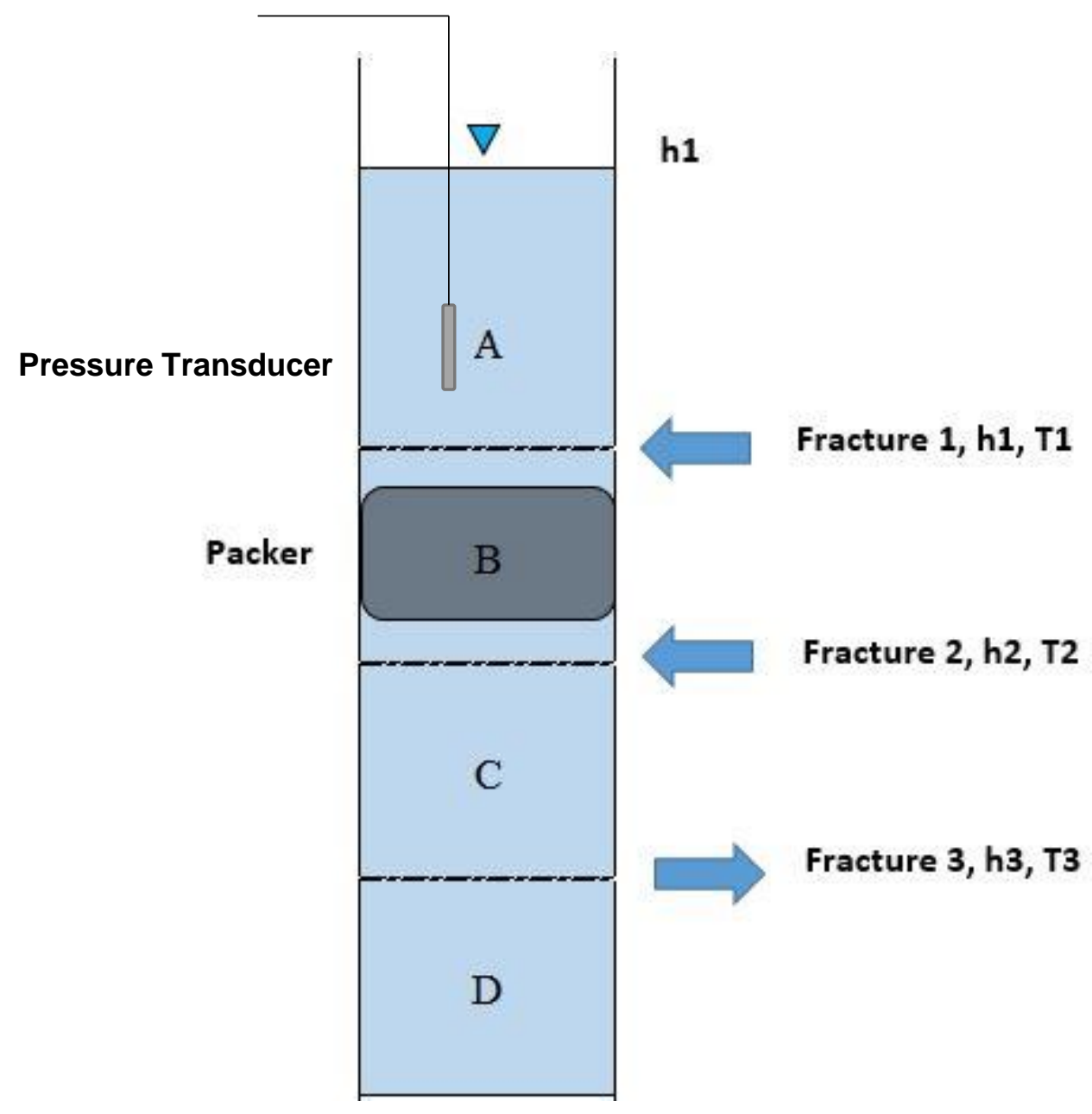

Figure 2: Packer lowered to depth B and is inflated to isolated fracture 1, the water level will rise to $h 1$. 


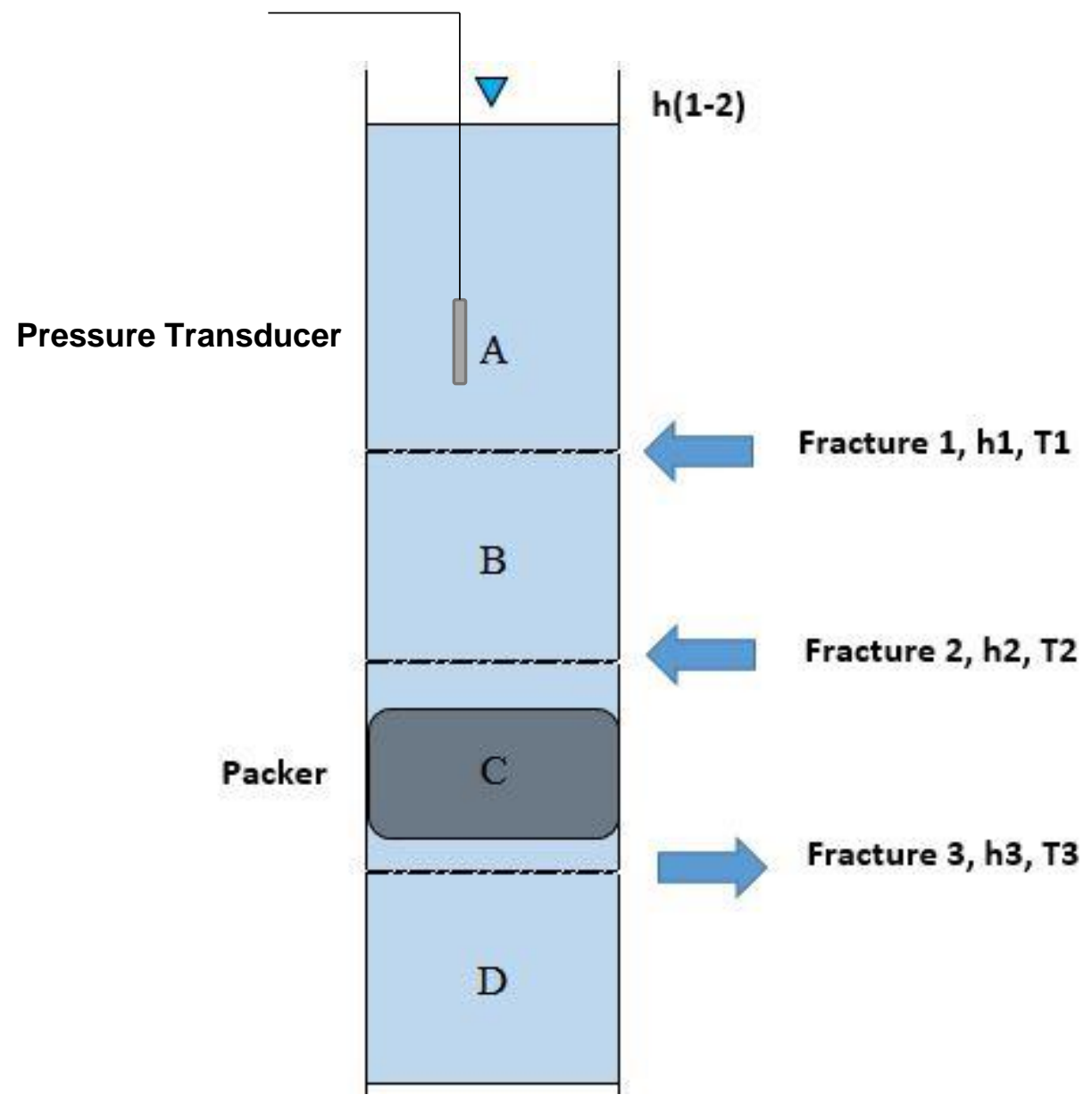

Figure 3: Packer lowered to depth $C$ and is inflated to isolated fractures 1 and 2, the water level will rise to a weighted average head, $\mathrm{h}(1-2)$. 


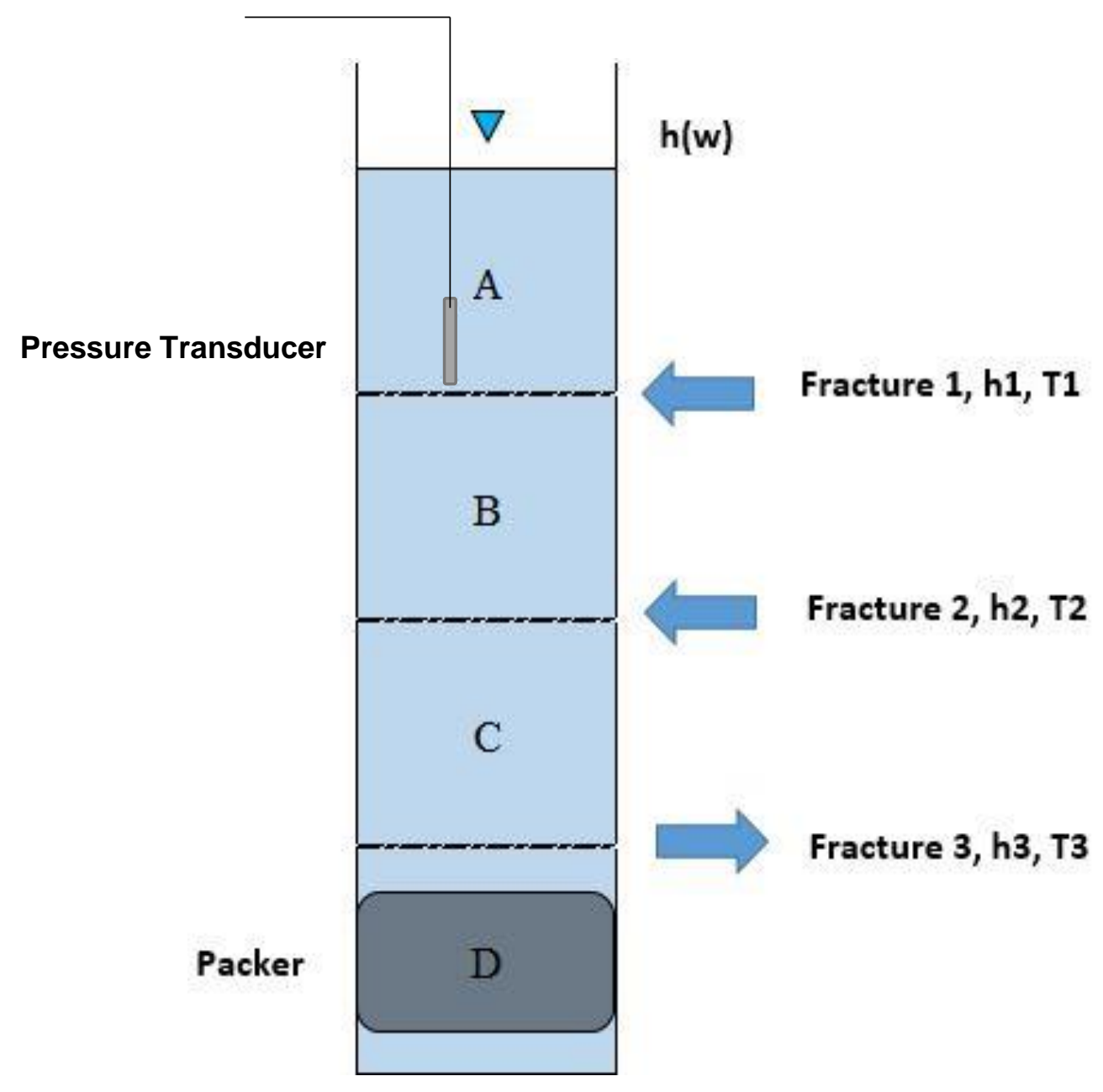

Figure 4: Packer lowered to depth $D$ and is inflated to isolate all intersecting fractures, the water level will rise to static water level, $\mathrm{h}(\mathrm{w})$. 


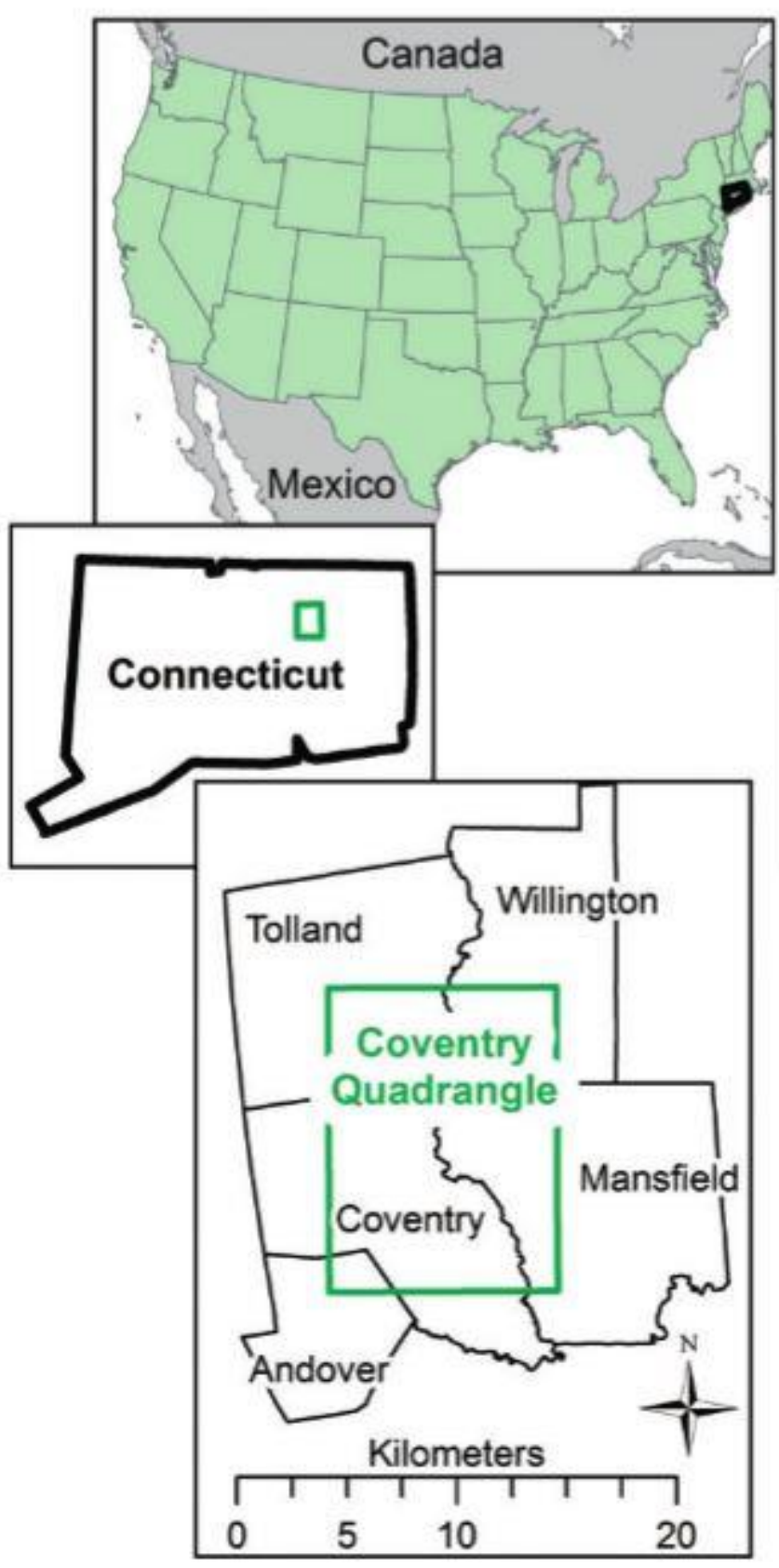

Figure 5: Location of the Coventry Quadrangle in the state of Connecticut, USA. (Metcalf, 2014) 


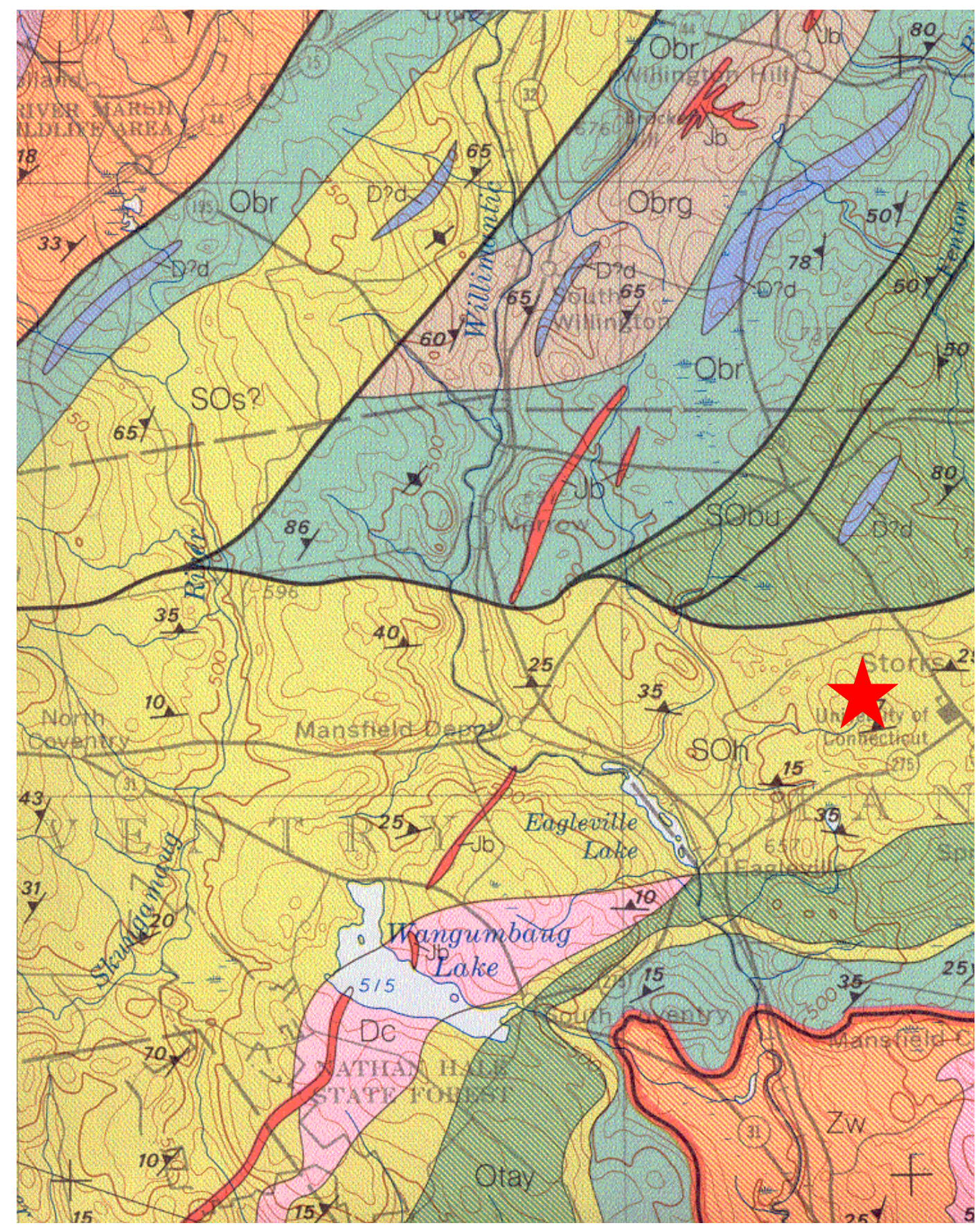

Figure 6: Generalized Bedrock Geologic Map of Coventry Quadrangle in the state of Connecticut, USA. Red Star indicates site locations. (Rogers, 1985) 


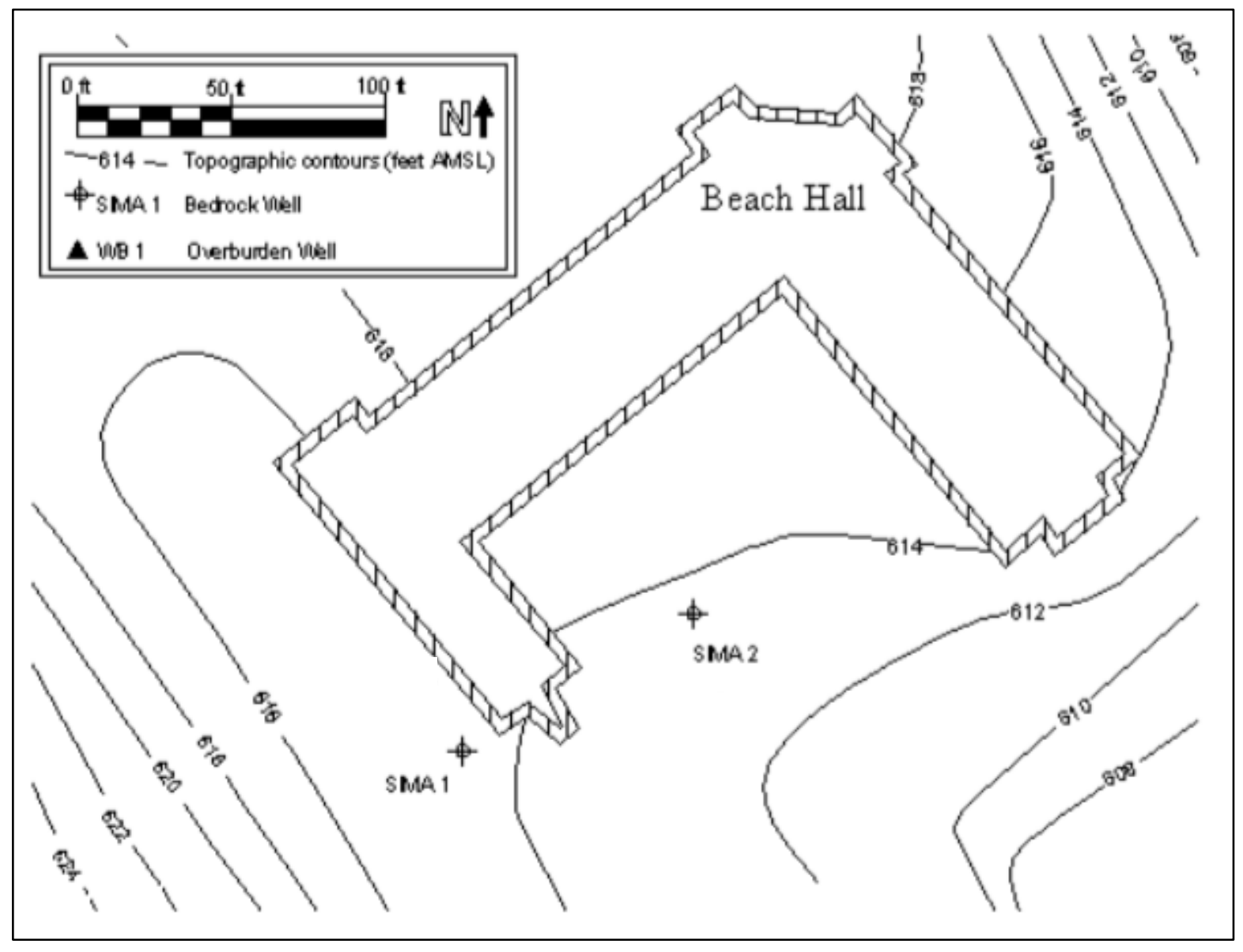

Figure 7: Site Map of Beach Hall (after Sernoffsky, 2004) (Topographic contours are in feet above mean sea level) 


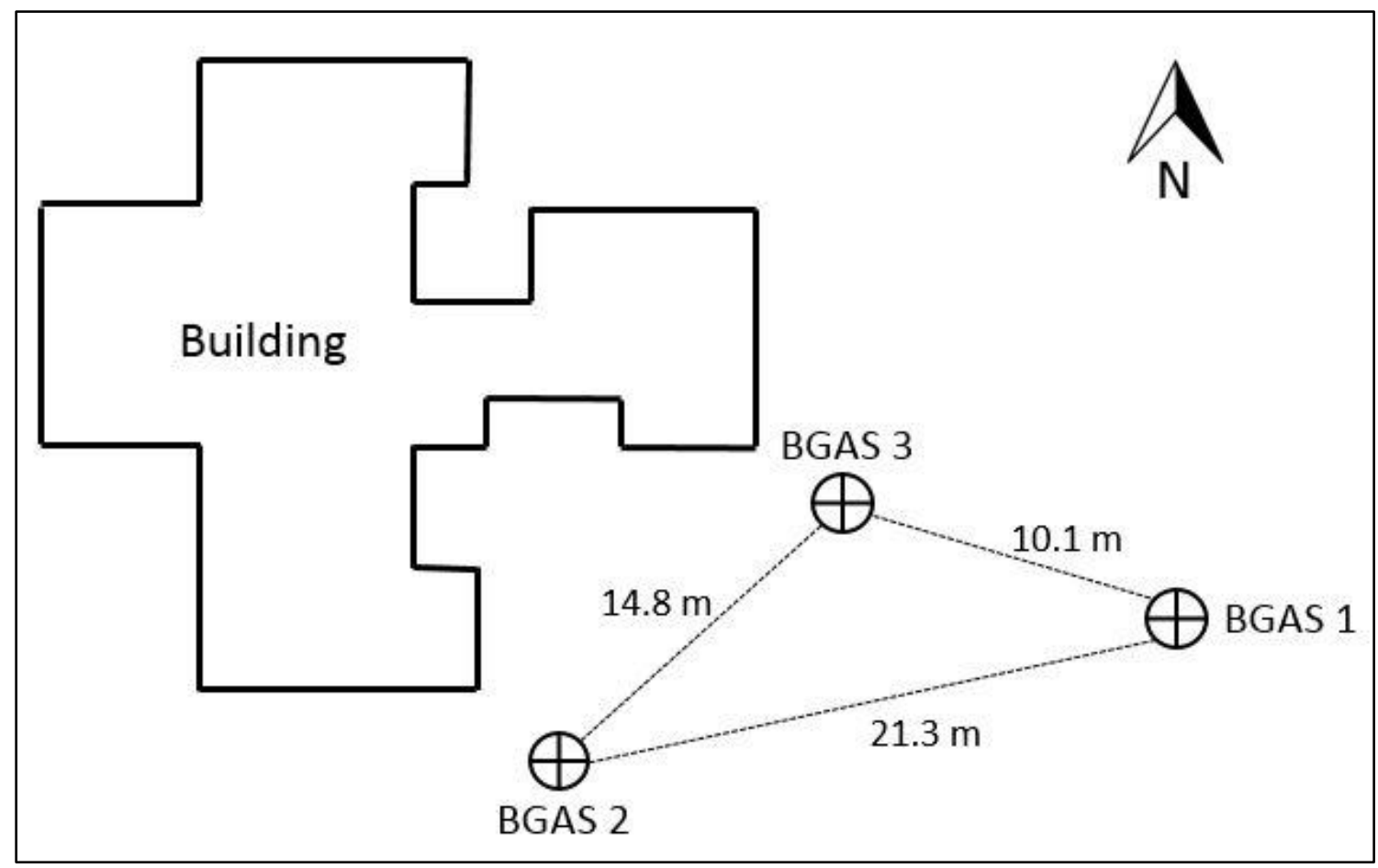

Figure 8: Site Map of UConn Depot Campus showing locations BGAS wells (after Brainerd, 2004)

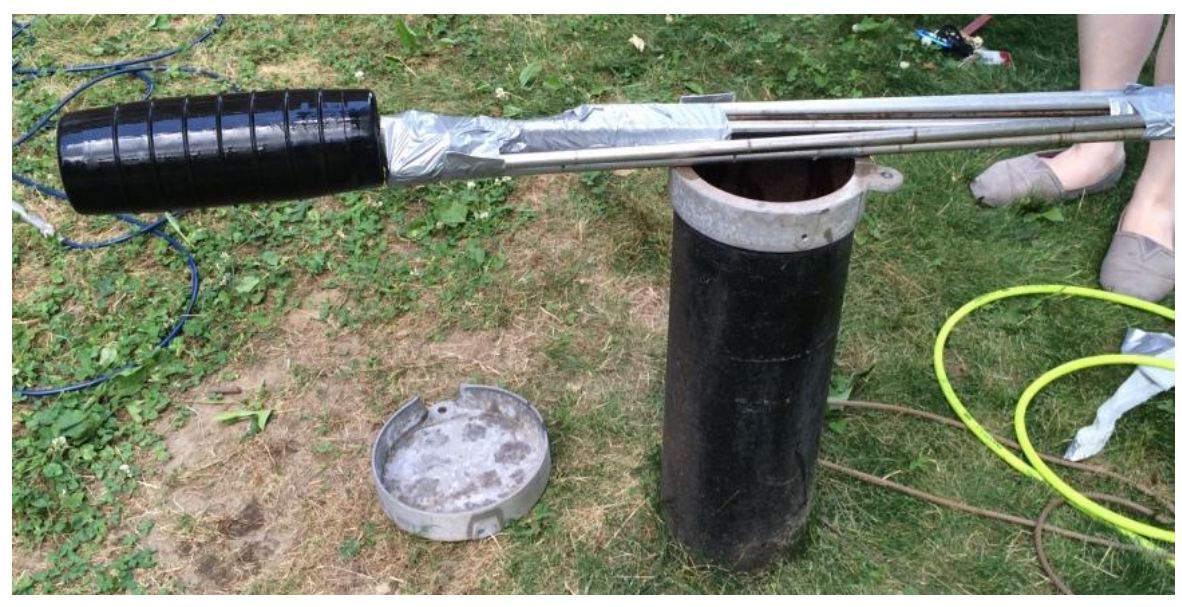

Figure 9: Single Packer Apparatus. Cherne® Multi-Sized Test-Ball. 


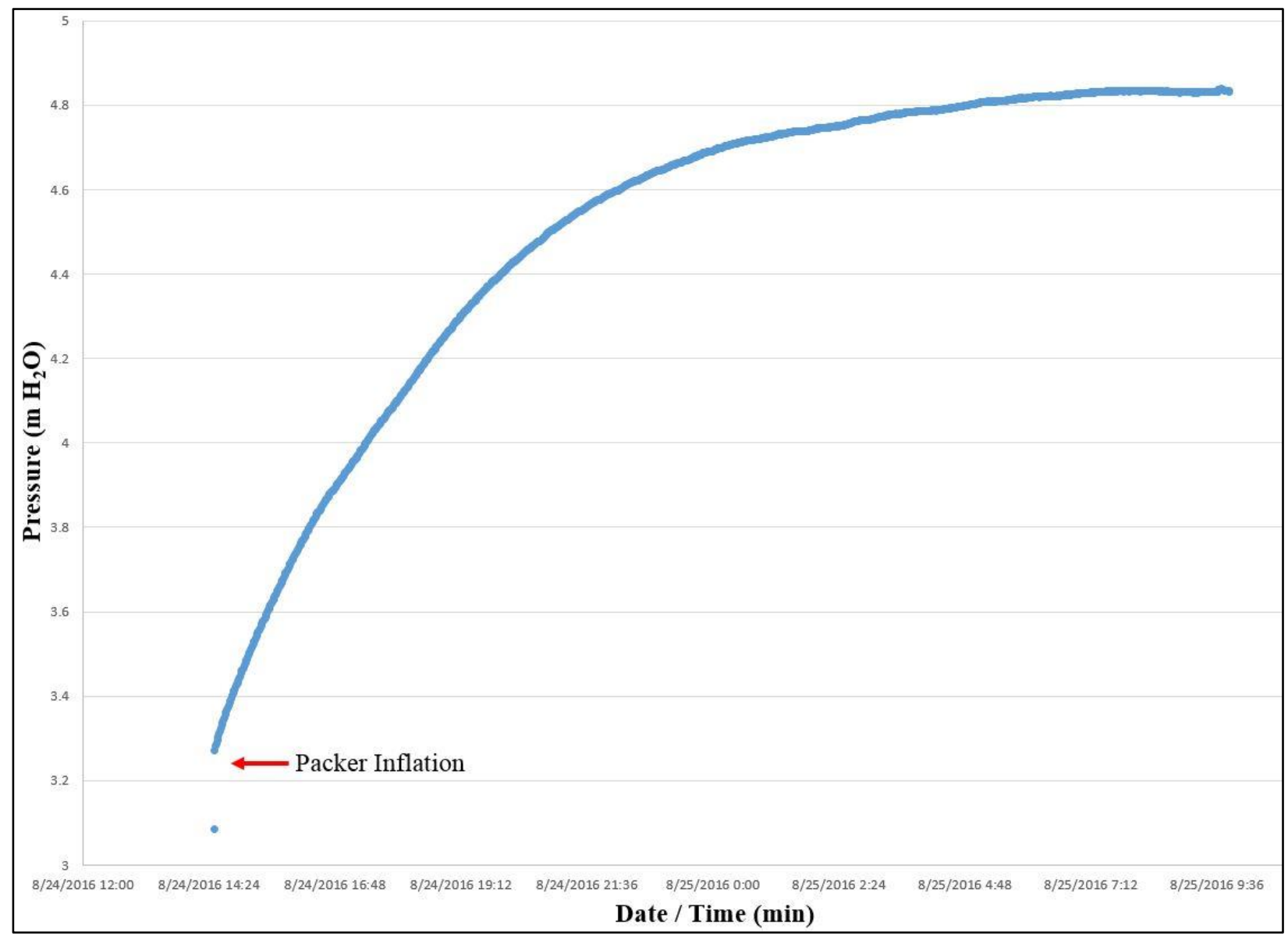

Figure 10: Example graph of water level recovery data as a function of time used to determine steady fracture hydraulic head and transmissivity. Initial increase of water level is representative of packer inflation. 


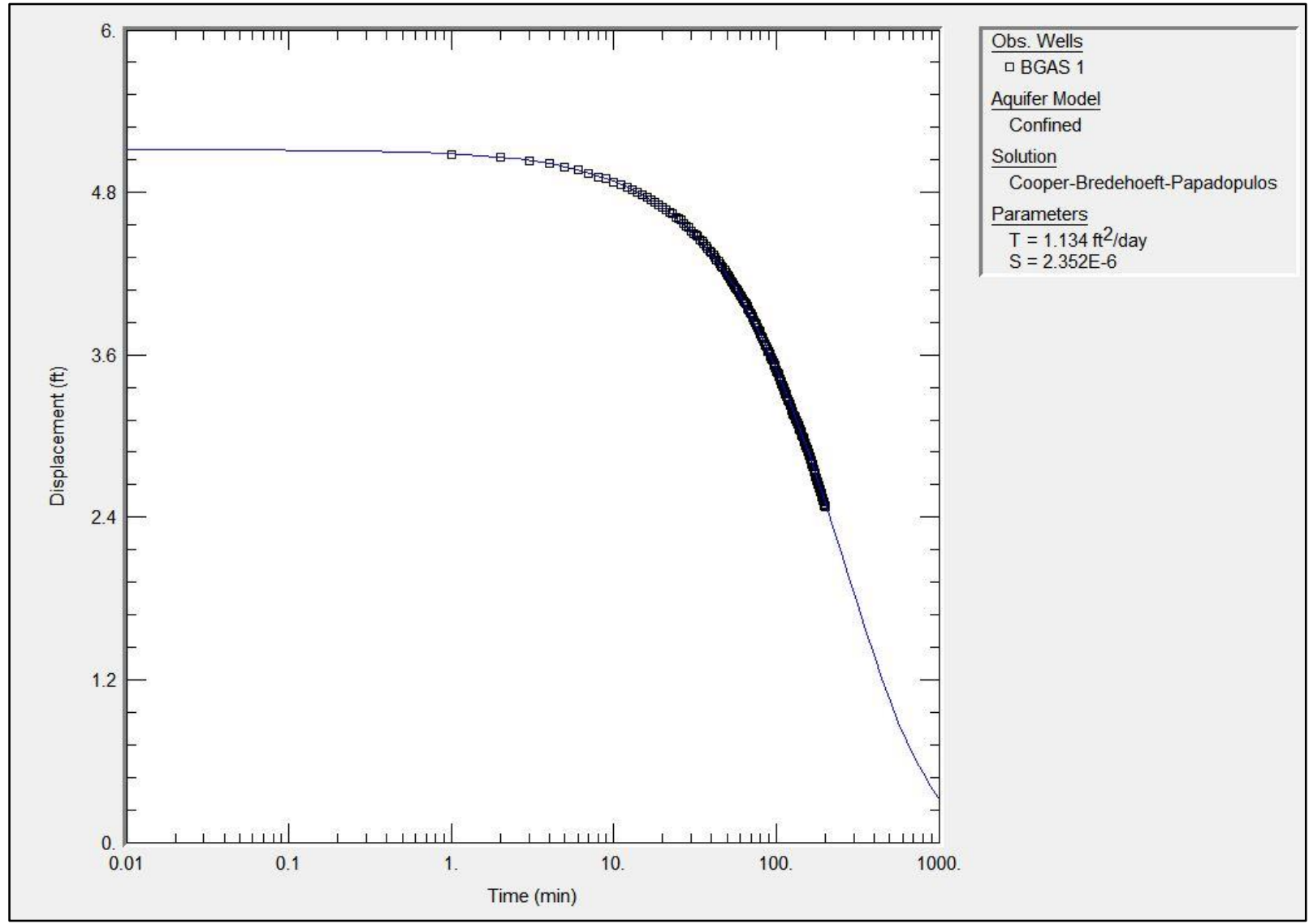

Figure 11: Type curve matching water level displacement data analyzed with Cooper-BredehoftPapadopulous (1967) mathematical solution used to determine fracture transmissivity. 


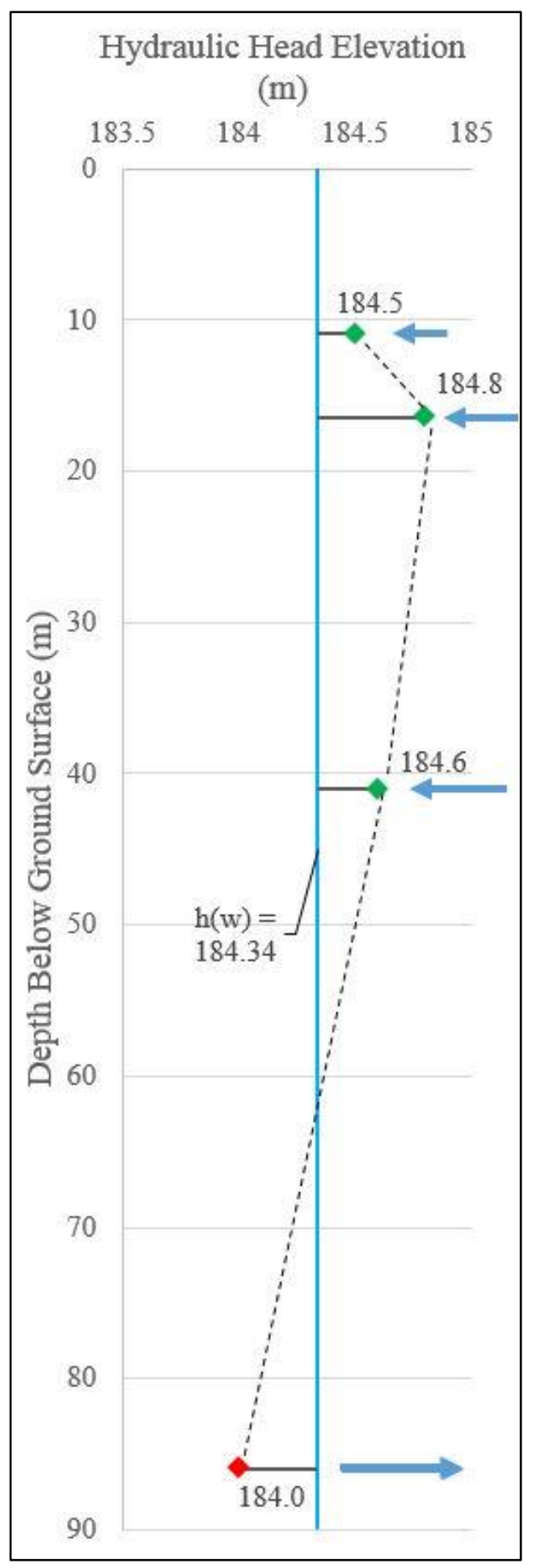

Figure 12: Hydraulic profile of SIMA 1 displaying fracture head elevation relative to static water level elevation, h(w). (Solid Light Blue Line = Static Water Level h(w), Green Diamonds $=$ Inflowing Fracture, Red Diamonds = Outflowing Fracture, Relative Magnitude of Blue Arrows $=$ Fracture Transmissivity, Dashed Black Line $=$ Hydraulic Gradient $)$ 


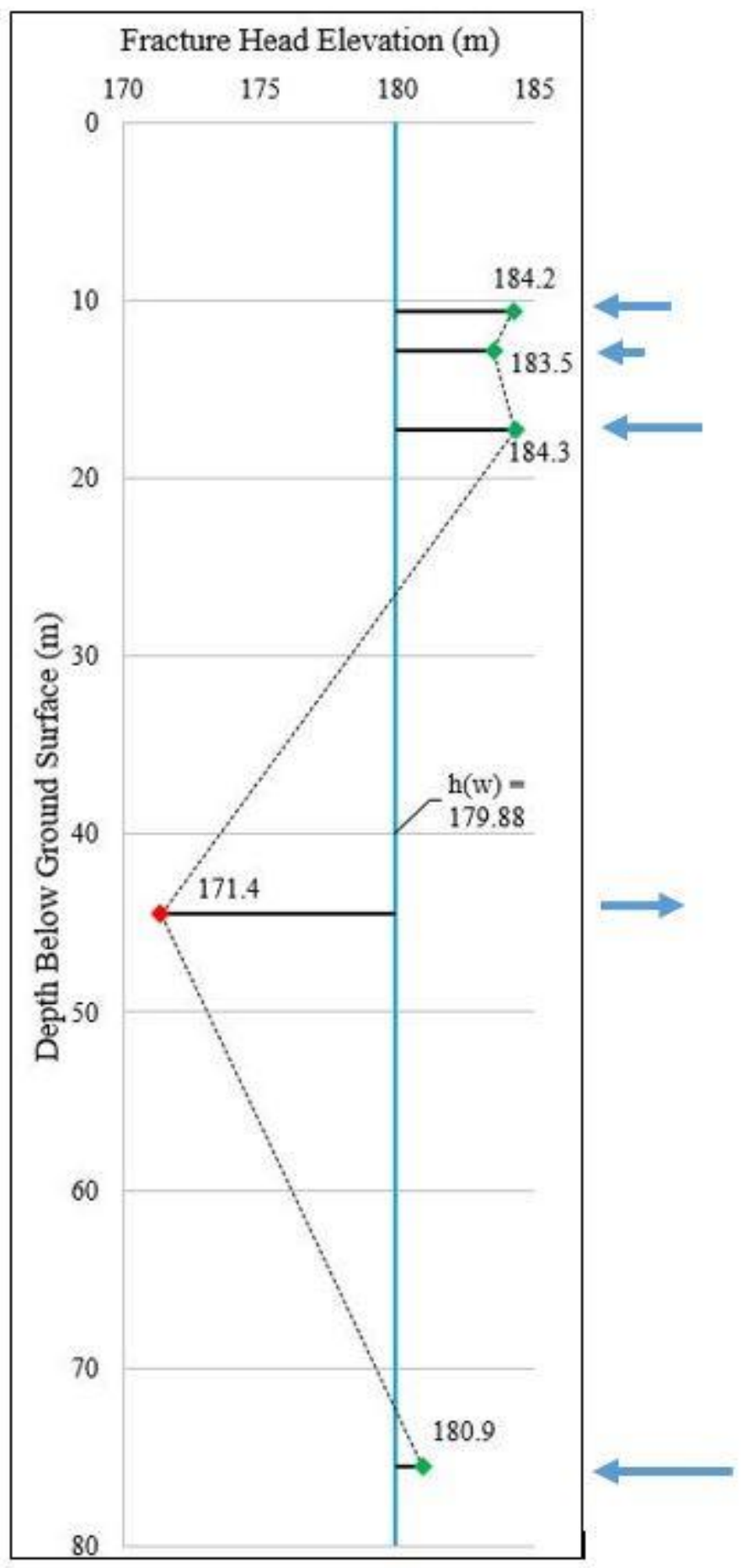

Figure 13: Hydraulic profile of SIMA 2 displaying fracture head elevation relative to static water level elevation, h(w). (Solid Light Blue Line = Static Water Level h(w), Green Diamonds $=$ Inflowing Fracture, Red Diamonds = Outflowing Fracture, Relative Magnitude of Blue Arrows $=$ Fracture Transmissivity, Dashed Black Line $=$ Hydraulic Gradient $)$ 


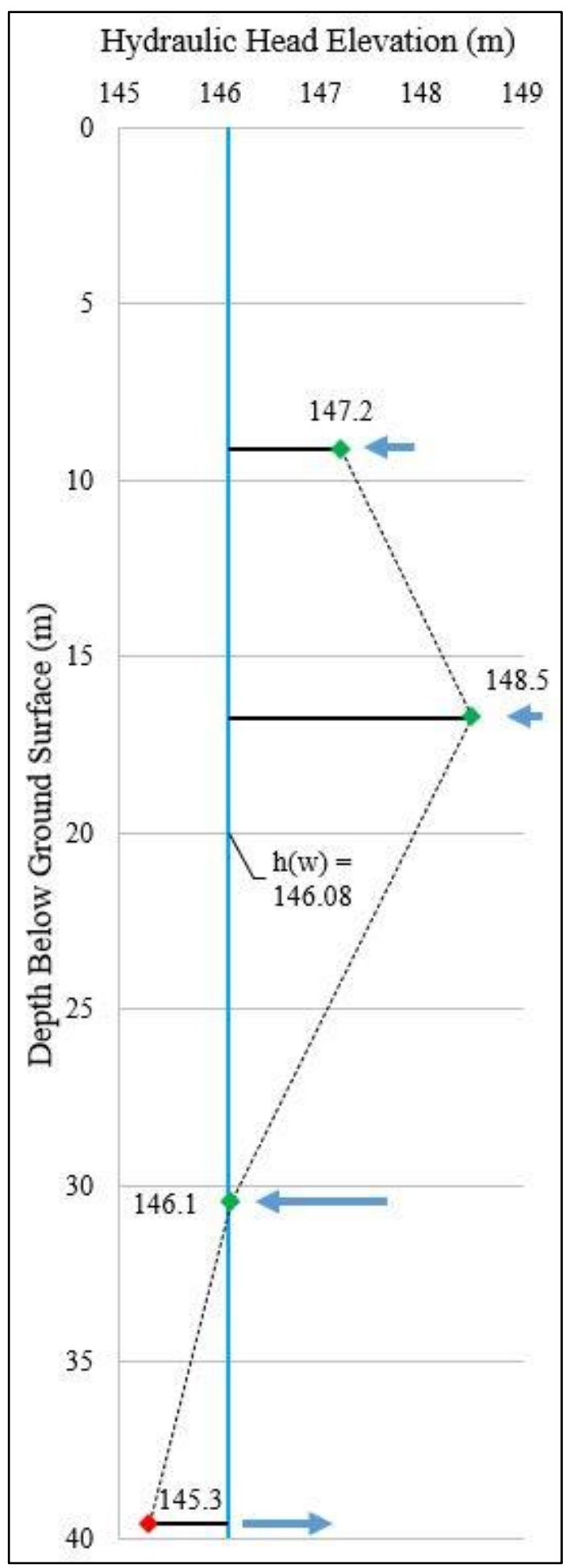

Figure 14: Hydraulic profile of BGAS 1 displaying fracture head elevation relative to static water level elevation, h(w). (Solid Light Blue Line = Static Water Level h(w), Green Diamonds = Inflowing Fracture, Red Diamonds = Outflowing Fracture, Relative Magnitude of Blue Arrows $=$ Fracture Transmissivity, Dashed Black Line $=$ Hydraulic Gradient $)$ 


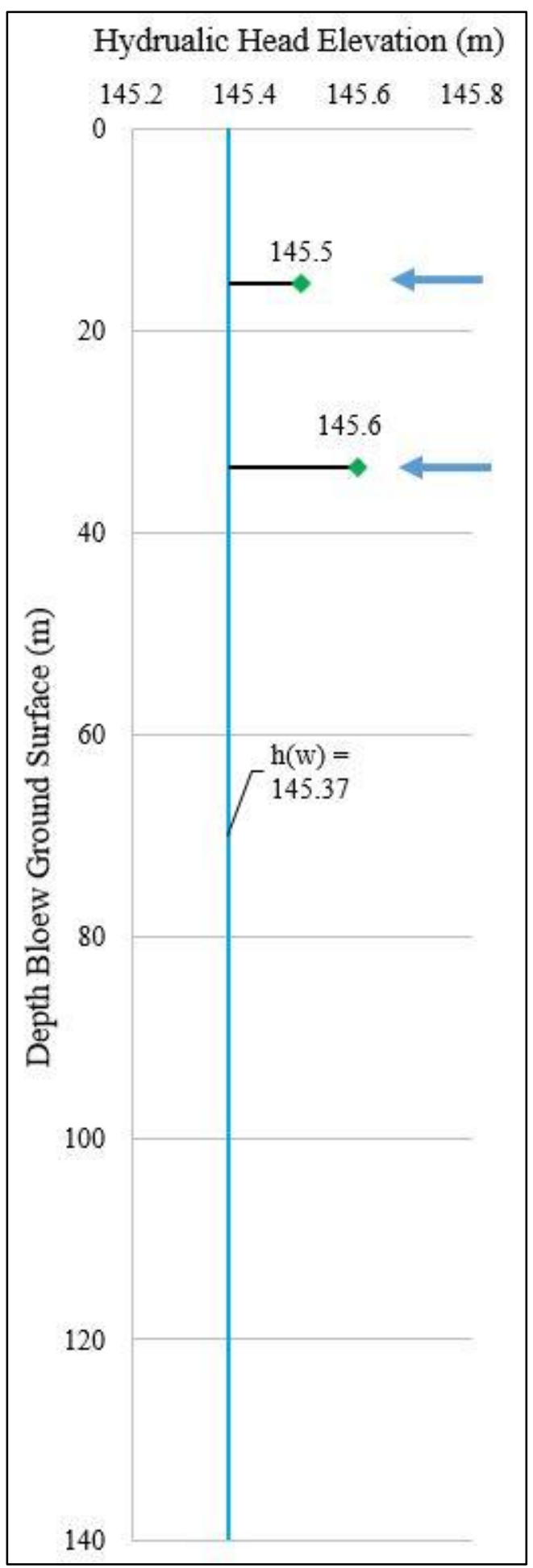

Figure 15: Hydraulic profile of BGAS 2 displaying fracture head elevation relative to static water level elevation, h(w). (Solid Light Blue Line = Static Water Level h(w), Green Diamonds = Inflowing Fracture, Red Diamonds = Outflowing Fracture, Relative Magnitude of Blue Arrows $=$ Fracture Transmissivity, Dashed Black Line $=$ Hydraulic Gradient $)$ 


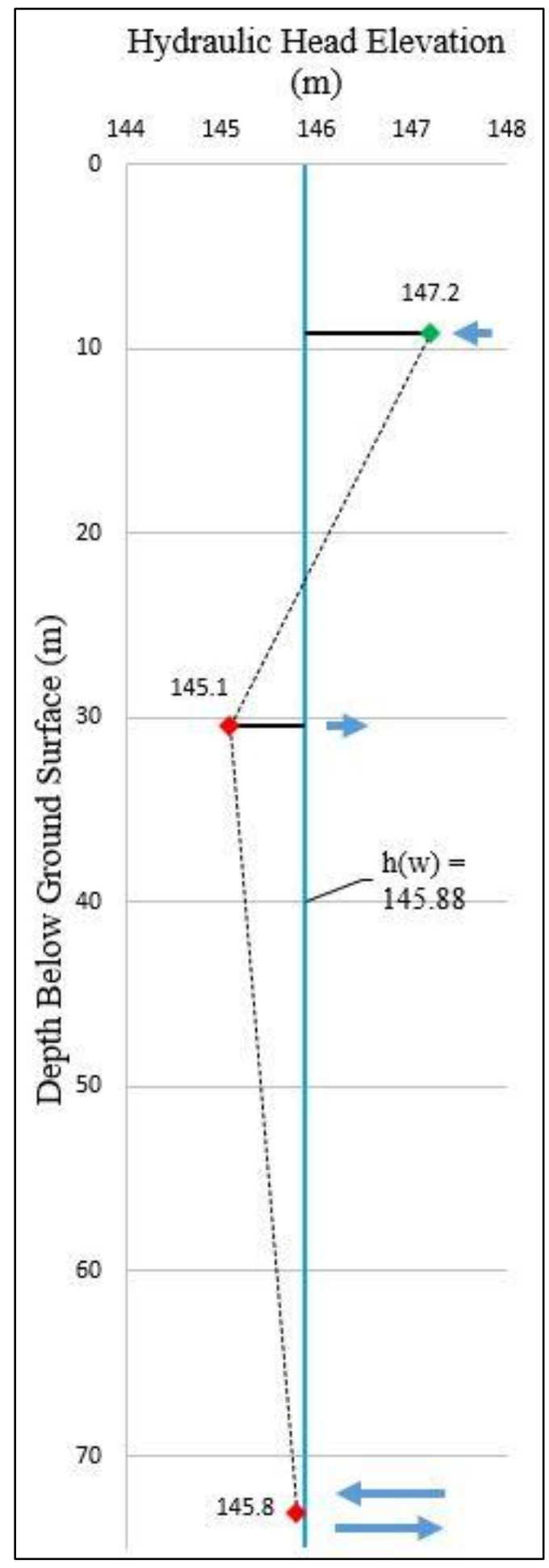

Figure 16: Hydraulic profile of BGAS 3 displaying fracture head elevation relative to static water level elevation, h(w). (Solid Light Blue Line = Static Water Level h(w), Green Diamonds $=$ Inflowing Fracture, Red Diamonds = Outflowing Fracture, Relative Magnitude of Blue Arrows $=$ Fracture Transmissivity, Dashed Black Line $=$ Hydraulic Gradient $)$ 

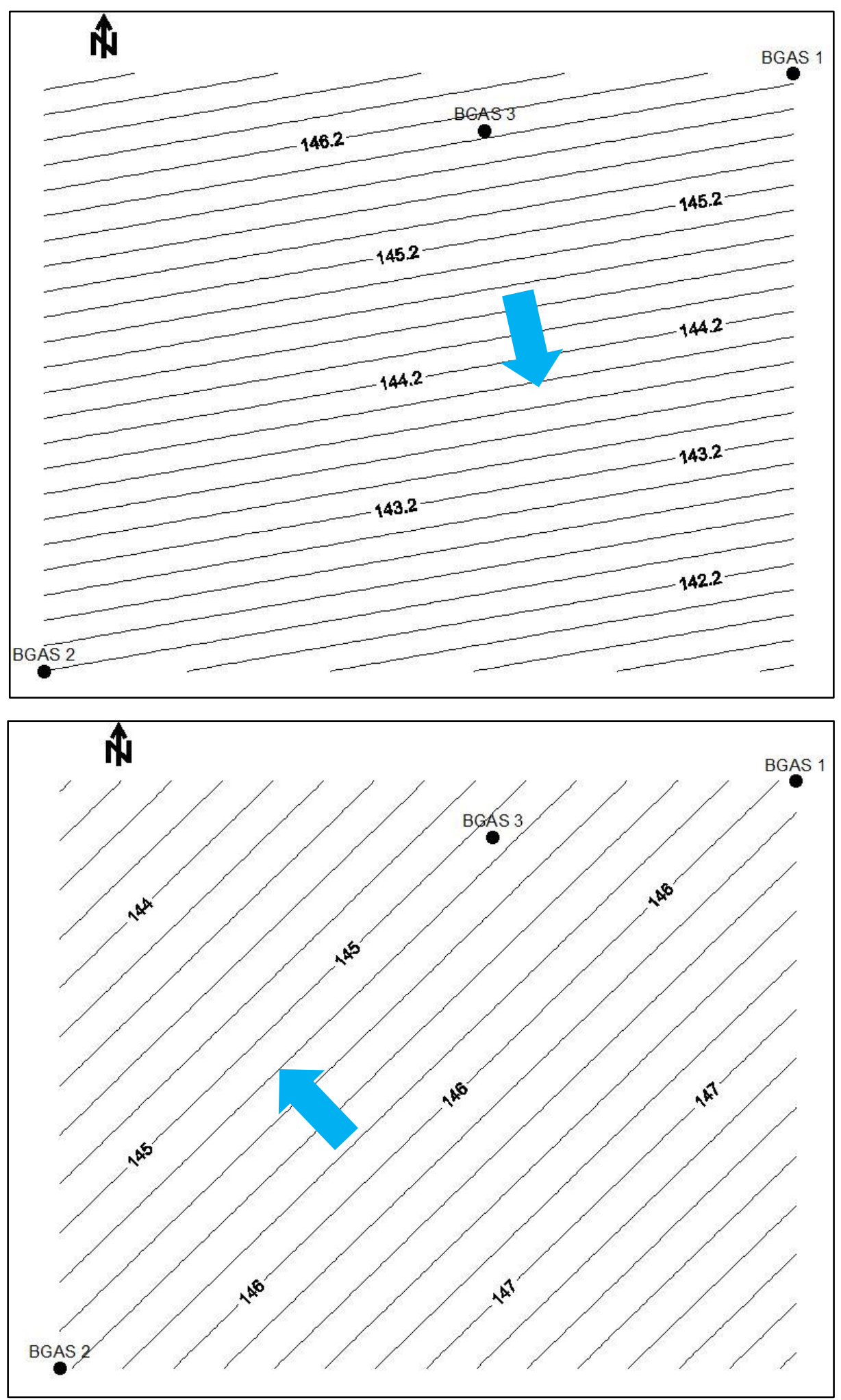

Figure 17: Water level contour maps of BGAS wells illustrating the contrast in apprarent ground water flow direction based on using the static well head elevations (Top) and the $30 \mathrm{~m}$ fracture head elevations (Bottom). (Blue Arrow = apparent ground water flow direction) 